\title{
Transgenic mouse lines for non-invasive ratiometric monitoring of intracellular chloride
}

\author{
Laura Batti ${ }^{1+}$, Marat Mukhtarov ${ }^{2,3+}$, Enrica Audero ${ }^{1}$, Anton Ivanov ${ }^{2}$, Rosa Chiara Paolicelli ${ }^{1}$, \\ Sandra Zurborg ${ }^{1}$, Cornelius Gross ${ }^{1}$, Piotr Bregestovski ${ }^{2 *}$ and Paul A. Heppenstall ${ }^{1 *}$ \\ Mouse Biology Unit, European Molecular Biology Laboratory, Monterotondo, Italy \\ 2 Inserm UMR1106, Brain Dynamics Institute, University Aix-Marseille, Marseille, France \\ ${ }^{3}$ Laboratory of Neurobiology, Department of Physiology of Human and Animals, Institute of Fundamental Medicine and Biology, Kazan Federal University, Kazan, \\ Russia
}

\section{Edited by:}

Daniele Arosio, National Research

Council of Italy, Italy

Reviewed by:

Laura Cancedda, Istituto Italiano di Tecnologia, Italy

Gia M. Ratto, Consiglio Nazionale delle Ricerche, Italy

*Correspondence:

Piotr Bregestovski, Inserm UMR1106, Brain Dynamics Institute,

University Aix-Marseille, 27

Boulevard Jean Moulin, 13385

Marseille Cedex 05, France.

e-mail: piotr.bregestovski@ univ-amu.fr:

Paul A. Heppenstall, Mouse Biology Unit, European Molecular Biology

Laboratory, Via Ramarini 32,

Monterotondo 00015, Italy.

e-mail: paul.heppenstall@embl.it

${ }^{\dagger}$ Equal participation
Chloride is the most abundant physiological anion and participates in a variety of cellular processes including trans-epithelial transport, cell volume regulation, and regulation of electrical excitability. The development of tools to monitor intracellular chloride concentration $\left(\left[\mathrm{Cl}_{\mathrm{i}}\right]\right)$ is therefore important for the evaluation of cellular function in normal and pathological conditions. Recently, several Cl-sensitive genetically encoded probes have been described which allow for non-invasive monitoring of $\left[\mathrm{Cl}_{\mathrm{i}}\right]$. Here we describe two mouse lines expressing a CFP-YFP-based $\mathrm{Cl}$ probe called $\mathrm{Cl}$-Sensor. First, we generated transgenic mice expressing $\mathrm{Cl}$-Sensor under the control of the mouse Thy 1 mini promoter. Cl-Sensor exhibited good expression from postnatal day two (P2) in neurons of the hippocampus and cortex, and its level increased strongly during development. Using simultaneous whole-cell monitoring of ionic currents and $\mathrm{Cl}$-dependent fluorescence, we determined that the apparent $E C_{50}$ for $\mathrm{Cl}_{i}$ was $46 \mathrm{mM}$, indicating that this line is appropriate for measuring neuronal $\left[\mathrm{Cl}_{\mathrm{i}}\right]$ in postnatal mice. We also describe a transgenic mouse reporter line for Cre-dependent conditional expression of $\mathrm{Cl}$-Sensor, which was targeted to the Rosa26 locus and by incorporating a strong exogenous promoter induced robust expression upon Cre-mediated recombination. We demonstrate high levels of tissue-specific expression in two different Cre-driver lines targeting cells of the myeloid lineage and peripheral sensory neurons. Using these mice the apparent $E C_{50}$ for $\mathrm{Cl}_{i}$ was estimated to be 61 and $54 \mathrm{mM}$ in macrophages and DRG, respectively. Our data suggest that these mouse lines will be useful models for ratiometric monitoring of $\mathrm{Cl}_{\mathrm{i}}$ in specific cell types in vivo.

Keywords: fluorescent biosensors, intracellular chloride, non-invasive monitoring, optogenetics, brain slices, dorsal root ganglia, macrophages

\section{INTRODUCTION}

Genetically encoded probes have become powerful tools for fluorescent analysis of the function and concentration of multiple intracellular ions and proteins (Bregestovski and Arosio, 2012; Depry et al., 2013; Perron et al., 2012). GFP derivatives with different colors have been successfully used to monitor $\mathrm{Ca}^{2+}$ (Miyawaki et al., 1997; Ohkura et al., 2012), pH (Kneen et al., 1998; Llopis et al., 1998; Miesenbock et al., 1998; Li and Tsien, 2012) and protein-protein interactions (Heim, 1999).

Over the last decade, several genetically encoded Cl-sensitive probes for measuring intracellular $\mathrm{Cl}$ concentration $\left([\mathrm{Cl}]_{\mathrm{i}}\right)$ have also been developed (Kuner and Augustine, 2000; Markova et al., 2008; Arosio et al., 2010). The first generation of these probes was based on the fact that the fluorescence intensity of yellow fluorescent protein (YFP) is quenched by increasing concentrations of $\mathrm{Cl}$ ions (Wachter and Remington, 1999). A further improvement on this approach was the design of ratiometric $\mathrm{Cl}$ indicators that allowed quantitative measurements independent of the expression level of the probe. This was first achieved by designing fusion constructs of YFP coupled to cyan fluorescent protein (CFP) through a polypeptide linker. CFP fluorescent intensity is independent of $\mathrm{Cl}$ concentration and thus acts as a reference point for normalizing expression levels (Kuner and Augustine, 2000). This probe, called Clomeleon, has been used for measurements of $[\mathrm{Cl}]_{\mathrm{i}}$ in cultured hippocampal neurons (Kuner and Augustine, 2000), in plant cells (Lorenzen et al., 2004) and in cells of the retina and brain slices (Duebel et al., 2006; Pond et al., 2006).

A number of transgenic mouse lines have been created by insertion of $\mathrm{pH} / \mathrm{Cl}$-sensitive YFP (Metzger et al., 2002) or Clomeleon (Berglund et al., 2008) DNA into the mouse genome. The most successful of these approaches relied upon random integration of a Clomeleon construct containing a Thyl mini promoter to drive expression in sub populations of neurons (Berglund et al., 2008). These mice have allowed imaging of $\mathrm{Cl}$ dynamics in inhibitory circuits of different brain areas (Berglund et al., 2008; Glykys et al., 2009) and in intact hippocampus (Dzhala et al., 2012).

A disadvantage of the Clomeleon sensor is that at physiological $\mathrm{pH}$ it has a rather low sensitivity to $\mathrm{Cl}$. The apparent $E C_{50}$ of Clomeleon is more than $100 \mathrm{mM}$ (Kuner and Augustine, 2000; Duebel et al., 2006) which is outside the range normally encountered in cells $\left([\mathrm{Cl}]_{\mathrm{i}}: 3-60 \mathrm{mM}\right)$ (Bregestovski et al., 
2009). Moreover, attempts to generate mouse lines with inducible expression of Clomeleon in defined cell types have been hindered by low expression levels of the probe (Berglund et al., 2008).

To address these issues, we have taken advantage of a new genetically encoded indicator termed Cl-Sensor (Markova et al., 2008; Waseem et al., 2010) that contains a triple mutation in YFP which renders it more sensitive to $\mathrm{Cl}$ [estimated apparent $E C_{50} \sim$ 30-50 mM (Markova et al., 2008; Waseem et al., 2010)]. We have created two mouse lines that express $\mathrm{Cl}$-Sensor either under the control of the Thyl mini promoter, or via Cre-mediated recombination from the Rosa26 locus. Here we describe the generation and characterization of these lines, and demonstrate that they allow for robust ratiometric monitoring of $[\mathrm{Cl}]_{\mathrm{i}}$ across different tissues.

\section{MATERIALS AND METHODS GENERATION OF TRANSGENIC MICE}

We generated Thy1::Cl-sensor mice because the Thyl promoter has been demonstrated to drive robust expression in a wide variety of neurons (Caroni, 1997; Arenkiel et al., 2007). Cl-Sensor cDNA was obtained from a Cl-Sensor expression vector (Markova et al., 2008) after AfeI-HincII digestion and blunt cloned into the XhoI site of the mouse Thy1.2 expression cassette (Caroni, 1997). Linearized, vector-free insert was prepared for pronuclear injection into C57BL/6J $\times$ DBA zygotes by agarose gel purification. Two founders carrying the transgene were identified and genotyped by PCR using the following primers: Thyl forward 5'-TCTGAGTGGCAAAGGACCTTAGG - $3^{\prime}$ and Cl-Sensor linker reverse $5^{\prime}$-TCCTTGGAAGTACAAATTCTC $-3^{\prime}$.

The cre-inducible Cl-Sensor construct was generated and assembled into the $\mathrm{XbaI}$ site of the Rosa26 targeting vector pROSA26 (Soriano, 1999) using classical recombinant DNA technology. ROSA26 locus was chosen because of the high efficiency of targeting by homologous recombination and because this locus gives ubiquitous expression across many tissues. The Cl-Sensor cassette consisted of the following individual sequence elements: a cytomegalovirus-immediate early (CMV-IE) promoter and a chicken beta-actin promoter (CAG); the adenovirus splice donor (SD) and splice acceptor (SA) site from plasmid pSAbgeo; an inverted wild-type loxP site (Sauer, 1987), a promoter-less neomycin resistance gene from plasmid pMC1NeopA (Thomas and Capecchi, 1987) including a Kozak consensus sequence (Kozak, 1987) followed by two successive polyadenylation sites from the bovine growth hormone gene; a mutant loxP2272 site (Siegel et al., 2001); the previously described Cl-Sensor cDNA (Markova et al., 2008) followed by the SV40 polyadenylation site, both sequences in reverse orientation relative to neomycin transcription; a wild-type loxP site and finally a mutant loxP2272 site in reverse orientation. The targeting vector was electroporated into A9 embryonic stem cells (ESC) and homologous recombinants identified by Southern blotting. Digested DNA using Bgll and BspHI underwent hybridization with a $3^{\prime}$ and $5^{\prime}$ probe, respectively. Using a $3^{\prime}$ probe two DNA fragments were visualized: a $6668 \mathrm{bp}$ (wild-type fragment) and a $9329 \mathrm{bp}$ mutant fragment. Using a $5^{\prime}$ probe two DNA fragments were visualized: a $7210 \mathrm{bp}$ (wildtype) fragment and $10450 \mathrm{bp}$ (mutant) fragment. A correctly identified clone was used for injection into C57BN/6 blastocysts followed by implantation of injected blastocysts into CD1 foster mothers, and backcross of male chimaeras with C57BL/6 females. All animal protocols were approved by the Italian Ministry of Health.

\section{SLICE PREPARATION AND ELECTROPHYSIOLOGICAL RECORDING}

Brain slices were prepared from postnatal day P3-P21 transgenic mice of both sexes. All animal protocols conformed to the French Public Health Service policy and the INSERM guidelines on the use of laboratory animals. Animals were rapidly decapitated and brains removed. Sagittal slices $(300 \mu \mathrm{m})$ were cut using a tissue slicer (Microm International, Germany) in ice-cold oxygenated modified artificial cerebrospinal fluid (ACSF), with $0.5 \mathrm{mM} \mathrm{CaCl}_{2}$ and $7 \mathrm{mM} \mathrm{MgSO}_{4}$, in which $\mathrm{Na}^{+}$was replaced by an equimolar concentration of choline. Slices were then transferred to oxygenated standard ACSF containing (in mM): 126 $\mathrm{NaCl}, 3.5 \mathrm{KCl}, 1.2 \mathrm{NaH}_{2} \mathrm{PO}_{4}, 25 \mathrm{NaHCO}_{3}, 1.3 \mathrm{MgCl}_{2}, 2.0 \mathrm{CaCl}_{2}$, and $10 \mathrm{D}$-glucose, $\mathrm{pH} 7.4$, at room temperature $\left(20-22^{\circ} \mathrm{C}\right)$ for at least $1 \mathrm{~h}$ before use. During recordings, slices were placed in a conventional fully submerged chamber superfused with ACSF $\left(32-34^{\circ} \mathrm{C}\right)$. Pyramidal cells in neocortical layers and CA1 and CA3 hippocampal regions were recorded. Whole-cell patchclamp recordings in voltage-clamp mode were performed using the EPC-9 amplifier (HEKA Elektronik, Germany). The patch pipette solution contained $(\mathrm{mM}): \mathrm{KCl}(0-135)$ or KGluconate (0-135); $\mathrm{MgCl}_{2} 2$; MgATP 2, HEPES/KOH 10, BAPTA 1; pH 7.3; 290 mOsm. Combination of KGluconate and $\mathrm{KCl}$ at a constant $\mathrm{K}^{+}$concentration of $135 \mathrm{mM}$ was used for $\mathrm{Cl}$ calibration of $\mathrm{Cl}-$ Sensor in Thy1::Cl-Sensor mice by five different $\mathrm{Cl}$ concentrations in pipette solution: 4, 10, 20, 60, and $135 \mathrm{mM}$. Pipettes were pulled from borosilicate glass capillaries (Harvard Apparatus Ltd, USA) and had resistances of 5-7 M $\Omega$. Upon transition from cellattached to whole-cell configuration, the holding potential was usually -80 or $-70 \mathrm{mV}$.

\section{CELL CULTURE AND WHOLE MOUNT PREPARATION Dissociated DRG neurons}

DRG primary cell cultures were prepared from Avil-Cre::ClSensor adult mice (8-20 weeks) as previously described (Caspani et al., 2009). Briefly, mouse DRG were dissected and incubated with $1 \mathrm{mg} / \mathrm{ml}$ collagenase IV (Sigma, Italy) for $30 \mathrm{~min}$ at $37^{\circ} \mathrm{C}$ and with $0.05 \%$ trypsin (GIBCO, Italy) for $30 \mathrm{~min}$ at $37^{\circ} \mathrm{C}$. The DRG were suspended in DMEM (GIBCO, Italy) containing 10\% heat-inactivated horse serum (GIBCO, Italy), $100 \mathrm{U}$ penicillin, and $100 \mu \mathrm{g} / \mathrm{ml}$ streptomycin (GIBCO, Italy). DRG were dissociated using 1000 and $200 \mu$ l pipet tips, and debris was removed with a $40 \mu \mathrm{m}$ cell strainer (BD Biosciences Europe, Belgium). Cells were plated in $100 \mu \mathrm{l}$ of medium on poly-L-lysine $(100 \mu \mathrm{g} / \mathrm{ml}$, Sigma, Italy) coated $35 \mathrm{~mm} \varnothing$ glass bottom dish (Ibidi, Martinsried, Germany) and left to adhere for $3 \mathrm{~h}$ before the addition of $2 \mathrm{ml}$ of medium. Experiments were conducted 24-48 $\mathrm{h}$ after plating of cells.

\section{Whole mount DRG preparation}

DRG were isolated from Avil-Cre::Cl-Sensor adult mice (8-20 weeks). DRG, together with ventral and dorsal fibers $(1 \mathrm{~cm}$ length 
each side) where rapidly dissected. During the dissection tissue was wet with cold and oxygenated ACSF of the following composition (in mM): $\mathrm{NaCl} 120 ; \mathrm{NaHCO}_{3} 26 ; \mathrm{NaH}_{2} \mathrm{PO}_{4}$ 1.25; KCl 2.5; Glucose $10 ; \mathrm{MgSO}_{4} 2 ; \mathrm{CaCl}_{2}$ 2. Isolated DRG were transferred to a holding chamber containing ACSF at room temperature $\left(20-21^{\circ} \mathrm{C}\right)$, bubbled with $95 \% \mathrm{O}_{2} / 5 \% \mathrm{O}_{2}$ and left to recover for at least $30 \mathrm{~min}$. The whole mount DRG was then transferred to an imaging chamber and a U-shaped stainless steel rod with 12 pieces of fine nylon filaments crossing from one side to the other was used to gently hold the ganglion in place within the imaging chamber. Tissue was continuously perfused with ACSF bubbled with $95 \% \mathrm{O}_{2} / 5 \% \mathrm{CO}_{2}$ from a $100 \mathrm{ml}$ reservoir at a flow rate of $2.5 \mathrm{ml} / \mathrm{min}$ at room temperature.

\section{Peritoneal macrophage primary cell cultures}

Peritoneal macrophage primary cell cultures were prepared from LysM-Cre::Cl-Sensor adult mice (8-20 weeks). Briefly, peritoneal macrophages were harvested via intraperitoneal lavage with $5 \mathrm{ml}$ of DMEM (GIBCO, Italy). Cells where plated in 200-400 $\mu$ l of DMEM medium on a petri dish and left to adhere for $2-3 \mathrm{~h}$. After one wash with medium to remove the non-adherent cells, cells were incubated on DMEM supplemented with $10 \%$ heatinactivated horse serum and $100 \mathrm{U}$ penicillin, and $100 \mu \mathrm{g} / \mathrm{ml}$ streptomycin (GIBCO, Italy) at $37^{\circ} \mathrm{C} 24-48 \mathrm{~h}$ before proceeding with the experiments.

For basal intracellular chloride measurements DRGs and macrophages cultures were kept in a HEPES buffer solution of the following composition (in mM): $\mathrm{NaCl} 140$; $\mathrm{NaOH} 4.55$; HEPES 10; $\mathrm{KCl} 4$; Glucose 5; $\mathrm{MgCl}_{2} 1 ; \mathrm{CaCl}_{2}$ 2. $\mathrm{pH}$ 7.4. For basal measurement on whole mount DRG, preparations were transferred to the imaging chamber described above and continuously perfused with oxygenated ACSF of the following composition (in mM): $\mathrm{NaCl} 120 ; \mathrm{NaHCO}_{3} 26 ; \mathrm{NaH}_{2} \mathrm{PO}_{4}$ 1.25; KCl 2.5; Glucose $10 ; \mathrm{MgSO}_{4} 2 ; \mathrm{CaCl}_{2} 2$.

\section{CALIBRATION OF CI-SENSOR IN RoSa26::CI-SENSOR MICE}

To calibrate the intracellular $\mathrm{Cl}$ dependence of the Cl-Sensor we used dissociated DRGs culture and peritoneal macrophages culture. Experiments were assessed in 1-2 days old cultures. All imaging experiments were conducted at $37^{\circ} \mathrm{C}$ in a humified chamber perfused with $5 \% \mathrm{CO}_{2}$. Different concentrations of $\mathrm{Cl}$ in the extracellular solution were created by mixing two "high potassium" solutions, containing in mM: (i) $164.8 \mathrm{KCl}$, 10 d-glucose, 20 HEPES, pH 7.3 and (ii) 164.8 K-gluconate, 10 d-glucose, 20 HEPES, $\mathrm{pH}$ 7.3. To increase the permeability of the cell membrane to $\mathrm{Cl}$ ions, 40 or $80 \mu \mathrm{M} \beta$-escin (Sigma, Italy) was added to neuronal or macrophages cultures, respectively. $\beta$-escin was dissolved in water and prepared freshly for each experiment. This suspension was stable for about $2 \mathrm{~h}$. Cells were incubated with $\beta$-escin for a maximum of $2 \mathrm{~min}$ and then intensely washed with HEPES buffer solution of the following composition (in $\mathrm{mM}$ ): $\mathrm{NaCl} 140 ; \mathrm{NaOH}$ 4.55; HEPES 10; $\mathrm{KCl} 4$; Glucose 5; $\mathrm{MgCl}_{2} 1 ; \mathrm{CaCl}_{2}$ 2. $\mathrm{pH}$ 7.4. The coverslip with cultured cells was then placed into the recording chamber and incubated with high potassium extracellular solution containing a given $\mathrm{Cl}$ concentration (from 0 to $150 \mathrm{mM} \mathrm{Cl}$ at $\mathrm{pH}$ 7.3). After a stabilization of the fluorescence, imaging experiments were carried out at the following $\mathrm{Cl}$ concentration in the extracellular solution: $0,10,20,30,50,100$, and $150 \mathrm{mM}$. The fluorescence responses of Cl-Sensor corresponding to specified $\mathrm{Cl}$ concentrations inside the cell were registered. Fluorescence data was fit with a Hill equation, which describes a sigmoidal curve.

$$
Y=A+\frac{B \times x^{H}}{E C 50^{H}+x^{H}}
$$

Where $y$ is the fluorescence $(440 / 514 \mathrm{~nm})$ value and $x$ the $[\mathrm{Cl}], A$ is the lowest $440 / 514 \mathrm{~nm}$ value, $B$ the highest $440 / 514 \mathrm{~nm}$ value, $E C_{50}$ is the midpoint of the curve and $H$ is the Hill coefficient. Values of $\mathrm{Cl}$ concentrations were then calculated according to the inverse function:

$$
[C l]=\left(\frac{E C 50^{H}}{\frac{B}{y-A}-1}\right)^{1 / H}
$$

For calibration of macrophages in culture the values were the following: $A=0.91, B=1.97, E C_{50}=60.79 \mathrm{mM}$ and $H=4.46$. For calibration of DRG cultures the variables were the following: $A=0.90, B=2.59, E C_{50}=54.46 \mathrm{mM}$ and $H=3.12$.

\section{REAL-TIME FLUORESCENCE IMAGING AND IMAGE ANALYSIS IN CELLS FROM Rosa26::CI-SENSOR MICE}

Dissociated DRG and macrophages were plated onto $35 \mathrm{~mm} \varnothing$ glass bottom dishes (Ibidi, Martinsried, Germany) and maintained using a microscope cage incubator, which allowed for a constant temperature $\left(37^{\circ} \mathrm{C}\right)$, humidity and $\mathrm{CO}_{2}(5 \%)$. Whole mount DRG and hippocampal slice were placed in the imaging chamber and continuously perfused with oxygenated ACSF at a flow rate of $2.5 \mathrm{ml} / \mathrm{min}$ at room temperature. Time Lapse video-microscopy was carried out using a Spinning Disk confocal Ultraview Vox (Perkin Elmer), interfaced with Volocity 6.0 software (Cellular imaging, Perkin Elmer). Diode solid state lasers, operating at 440 and $514 \mathrm{~nm}$ were used as excitation sources for the CFP and YFP, power was set at the same percentage for both lasers. Band pass emission filtercubes of 485 (W60) and 587 (W125), were used for the acquisition.

Images were acquired using a Hamamatsu EMCCD camera; exposure time and camera sensitivity were set equal for both channels. The recording protocol was designed with an initial equilibration time of the $440 / 514 \mathrm{~nm}$ ratio, and afterwards images were acquired every minute. The duration of excitation for the two lasers was $606 \mathrm{~ms}$.

Images analysis was carried out using ImageJ. Ratios of images acquired upon excitation at $440 \mathrm{~nm}$ and those obtained upon excitation at $514 \mathrm{~nm}(440 / 514)$ were calculated by dividing the two thresholded images. Mean gray intensity value for each cell was then calculated manually. Results are presented as mean \pm SEM. The data were analyzed by Student's $t$-test. Pearson's correlation analysis was used to correlate cell size and intracellular chloride concentration. A $p$-value $<0.05$ was accepted as significant. 


\section{REAL-TIME FLUORESCENCE IMAGING OF NEURONS IN SLICES FROM Thy1::CI-SENSOR MICE}

Fluorescence images were acquired using a customized digital imaging microscope. Excitation of the CFP and YFP in Cl-Sensor expressing cells in slices from Thy1::Cl-Sensor mice at wavelengths of 440 and $480 \mathrm{~nm}$ was achieved using a 1-nm-bandwidth polychromatic light selector equipped with a Polychrome V (150 W xenon lamp, Till Photonics, Germany). Light intensity was attenuated using neutral density filters. A dichroic mirror (495 nm; Omega Optics, USA) was used to deflect light onto the samples. Fluorescence was visualized using an upright microscope (Axioskop) equipped with a $60 \times$ water-immersion objective (n.a. 0.9; LumPlanFL, Olympus, USA). Fluorescent emitted light passed to a 16-bit electron multiplying chargecoupled device digital camera system equipped with an image intensifier (Andor iXon EM+; Andor Technology PLC, Northern Ireland). Images were acquired on a computer via a DMA serial transfer. All peripheral hardware control, image acquisition and image processing were achieved using customized software iQ (Andor Technology PLC, Northern Ireland). The average fluorescence intensity of each region of interest (ROI) was measured. Mean background fluorescence (measured from a nonfluorescent area) was subtracted and the ratio $(R)$ intensities $F_{440} / F_{480}$ (mentioned above) were determined. Sampling interval was usually 10 or $5 \mathrm{~s}$ in some cases and duration of excitation was $10-20 \mathrm{~ms}$.

\section{RESULTS}

\section{GENERATION OF CHLORIDE SENSOR TRANSGENIC MICE}

We generated two transgenic mouse lines for $\mathrm{Cl}$-Sensor, using either the mouse Thyl mini promoter or a Cre-dependent inducible approach.

\section{Thy1 MICE EXPRESSING CI-SENSOR}

In the first approach, we used an expression cassette containing a $6.5 \mathrm{~kb}$ genomic DNA fragment of the Thyl gene extending from the promoter to exon 4, but where exon 3 and its flanking introns were replaced by a XhoI linker (Caroni, 1997). This vector has been shown to drive strong constitutive transgene expression in neurons of postnatal (P6-12) and adult mice (Aigner et al., 1995). The Cl-Sensor cDNA was cloned at the level of the XhoI site and the purified insert Thy1::Cl-Sensor was injected into C57BL/6J $\times$ DBA pronuclei (Figure 1). Two transgenic founders were identified and analyzed for $\mathrm{Cl}$-Sensor expression. Expression was observed from P2 and increased strongly with development. At P2-P22 Cl-Sensor fluorescence was observed in hippocampus, particularly in CA1 and CA3, and neocortex (Figures 1A,B, 2, 4A,B, 5A).

We performed a comparative analysis of Cl-Sensor expression in hippocampus and cortex by monitoring fluorescence in brain slices from animals of different ages (from P2-P3 to P11) during excitation of the Cl-independent CFP component (with $440 \mathrm{~nm}$ wavelength) and recording in identical conditions. As illustrate

A

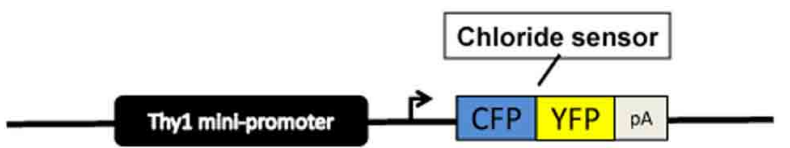

B
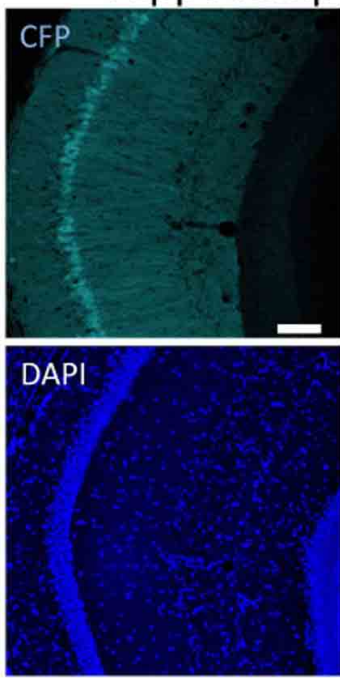
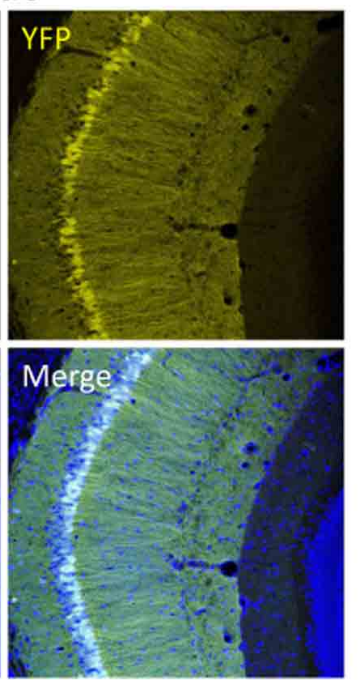

FIGURE 1 | Expression of $\mathrm{Cl}$-Sensor in Thy 1::Cl-sensor transgenic mice. (A) The Thy $1:: \mathrm{Cl}$-Sensor construct was constructed by fusing a fragment containing minimal regulatory elements and the promoter of the Thy1 gene upstream to the coding sequence of the $\mathrm{Cl}$-Sensor followed by a SV40 polyadenylation signal. (B and C) Representative z-stack projection images of the CA1 region of the hippocampus in a
C
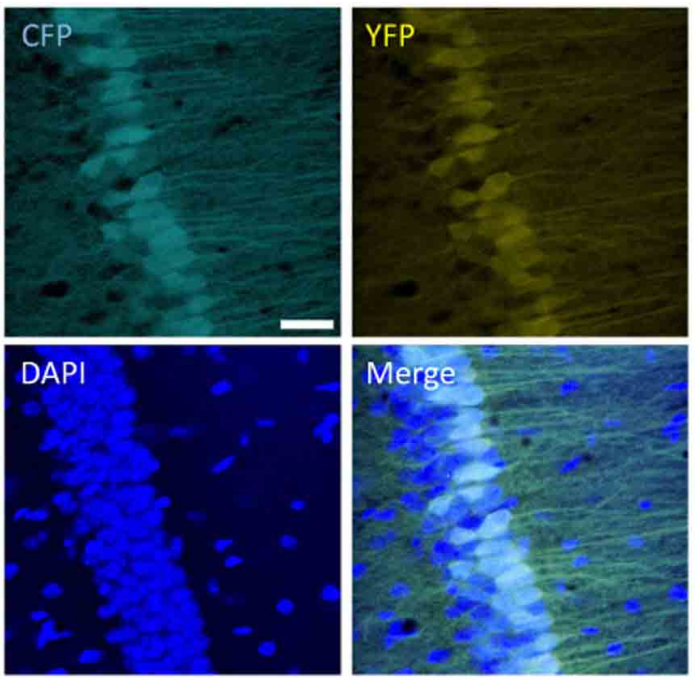

Thy $1:: \mathrm{Cl}$-Sensor transgenic mouse showing CFP (upper left), YFP (upper right), and DAPI (lower left), and merged (lower right) fluorescence at (B) $20 \times$ magnification, scale bar corresponds to $30 \mu \mathrm{m}$ and (C) $40 \times$ magnification, scale bar corresponds to $100 \mu \mathrm{m}$. Cl-Sensor expression was found in a mosaic pattern in most, but not all CA1 pyramidal neurons. 


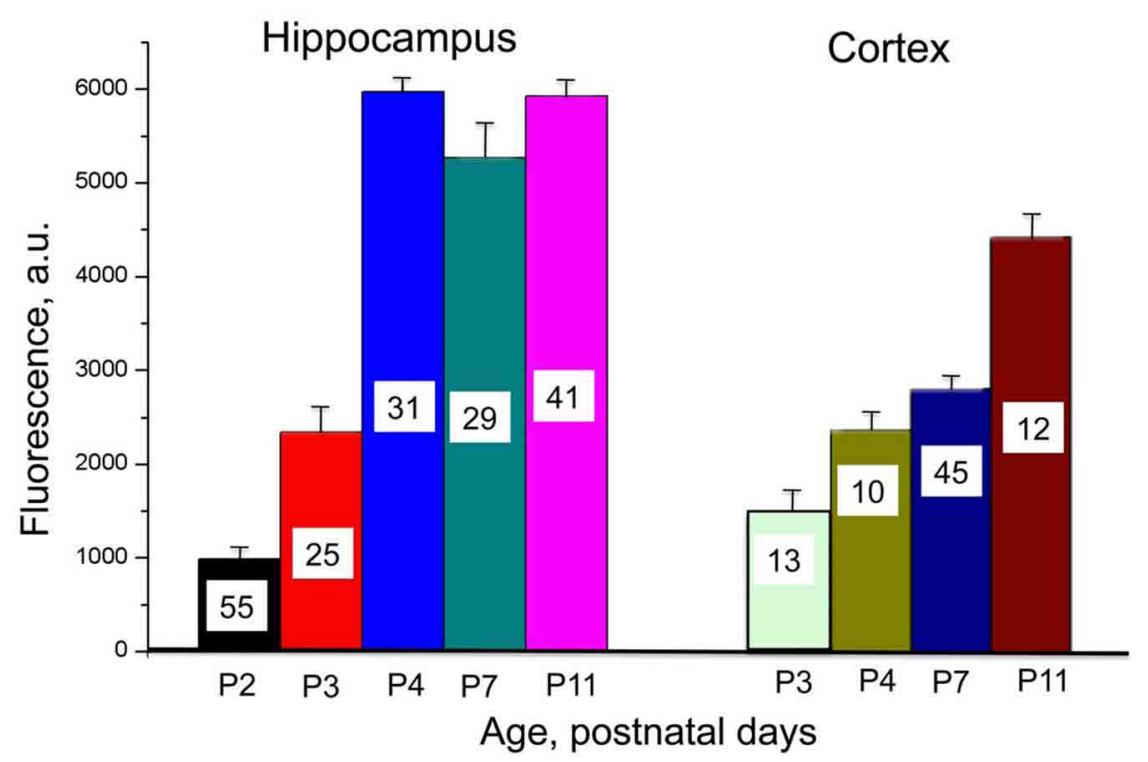

FIGURE 2 | Developmental profile of Cl-Sensor expression in hippocampus and cortex in Thy1::Cl-Sensor transgenic mice. Mean values of fluorescence induced by excitation of neurons from brain slices in hippocampus (left) and cortex (right) at different ages (shown below columns). An excitation wavelength of $440 \mathrm{~nm}$ for a duration of $20 \mathrm{~ms}$ was used with a $\times 60$ objective. Bars are mean \pm SEM values. Number of analyzed cells for each age is shown in columns. in Figure 2, robust increase in the fluorescence was observed in hippocampus, which reached a maximal level at P4. In contrast, in the cortex the Cl-Sensor expression developed slower and even at P11 it expression was lower than in hippocampus (Figure 2).

\section{CRE-INDUCIBLE CI-SENSOR MICE}

To generate an inducible Cl-Sensor line a Cre-inducible ClSensor-cassette was targeted to the Rosa26 locus by homologous recombination in ESC (Figure 3). The targeting construct was designed to give strong expression of Cl-Sensor in the absence of leakiness. To this end we included a strong CAG promoter upstream of the coding sequence and inserted the Cl-Sensor in an inverted orientation. As shown in Figure 3B the specific position of the two loxP sites allows a Cre-dependent inversion of the intervening sequences at either the loxP or loxP2272 sites, followed by irreversible excision of the neomycin stop cassette along with its loxP or loxP2272 site (Luche et al., 2007). Southern Blot confirmed appropriate homologous recombination on ES cell targeted clones and positive clones were selected for blastocyst injection.

\section{CALIBRATION OF CI-SENSOR IN BRAIN SLICES FROM Thy1 MICE}

Expression of Cl-Sensor was observed from P2 and its intensity increased with development (Figure 2). To evaluate the sensitivity of Cl-Sensor we used simultaneous monitoring of whole-cell currents and fluorescent signals in neurons from brain slices of transgenic mice (Figure 4B). Whole-cell recordings were performed with five different $\mathrm{Cl}$ concentrations in the pipette solution $\left([\mathrm{Cl}]_{\mathrm{p}}\right): 4,10,20,60$, and $135 \mathrm{mM}$. For ratiometric estimation of $[\mathrm{Cl}]_{\mathrm{i}}$, the ratio $R_{C l}=F_{440} / F_{480}$ was used.
Figure 4C illustrates relative changes in $[\mathrm{Cl}]_{\mathrm{i}}$ upon transition from cell attached to whole cell configuration from three cells in brain slices from P15 mouse using pipettes with solutions containing 4,60 , and $135 \mathrm{mM} \mathrm{Cl}$. $R_{C l 0}$ corresponds to $[\mathrm{Cl}]_{\mathrm{i}}$ in cell attached mode, i.e., to the native concentration of $\mathrm{Cl}$ in cytoplasm of the recorded cell. Breaking the membrane to obtain whole-cell configuration with the pipette containing $135 \mathrm{mM} \mathrm{Cl}$ (holding potential $-80 \mathrm{mV}$ ) resulted in an increase of $R_{C l} / R_{C l 0}$, corresponding to elevation of $[\mathrm{Cl}]_{\mathrm{i}}$. Interestingly, further increase in $R_{C l}$ was observed at depolarization of the cell to $0 \mathrm{mV}$ (Figure 4C). This suggest that $[\mathrm{Cl}]_{\mathrm{i}}$ in the cell did not reach the $[\mathrm{Cl}]_{\mathrm{p}}$ value at $V_{h}=-80 \mathrm{mV}$. Similar but slightly lower changes in $R_{C l}$ were observed in the cell recorded with the pipette containing $60 \mathrm{mM} \mathrm{Cl}$. Rupture of the membrane with the pipette containing $4 \mathrm{mM} \mathrm{Cl}$ produced a small increase in $R_{C l} / R_{C l 0}$, indicating that the basal value of $[\mathrm{Cl}]_{\mathrm{i}}$ in the cytoplasm of the neuron was lower than $4 \mathrm{mM}$. After reaching a maximal value, usually a decrease in the ratio was observed (Figure 4C), presumably due to pumping out of $\mathrm{Cl}$ by transporters (Pellegrino et al., 2011). Maximal values of $R_{C l}$ were used for obtaining the calibration curve. For high $[\mathrm{Cl}]_{\mathrm{p}}=60 \mathrm{mM}$ and $135 \mathrm{mM}$ the $R_{C l}$ values at $V_{h}=0 \mathrm{mV}$ were used while for lower $[\mathrm{Cl}]_{\mathrm{p}}=4,10$, and $20 \mathrm{mM}$ the holding potential always was kept at -80 or $-70 \mathrm{mV}$ (Figure 4C).

In slices from Thy1::Cl-Sensor mice the calibration curve obtained from neurons recorded with pipettes containing five different $[\mathrm{Cl}]_{\mathrm{p}}$ (Figure 4D) was best fit with a Logistic DoseResponse Sigmoidal curve using the OriginPro 8.5 program with the formula:

$$
R_{C l}=A 2+\frac{A 1-A 2}{1+\left(\frac{[C l]_{i}}{K_{d}}\right)^{p}},
$$


A
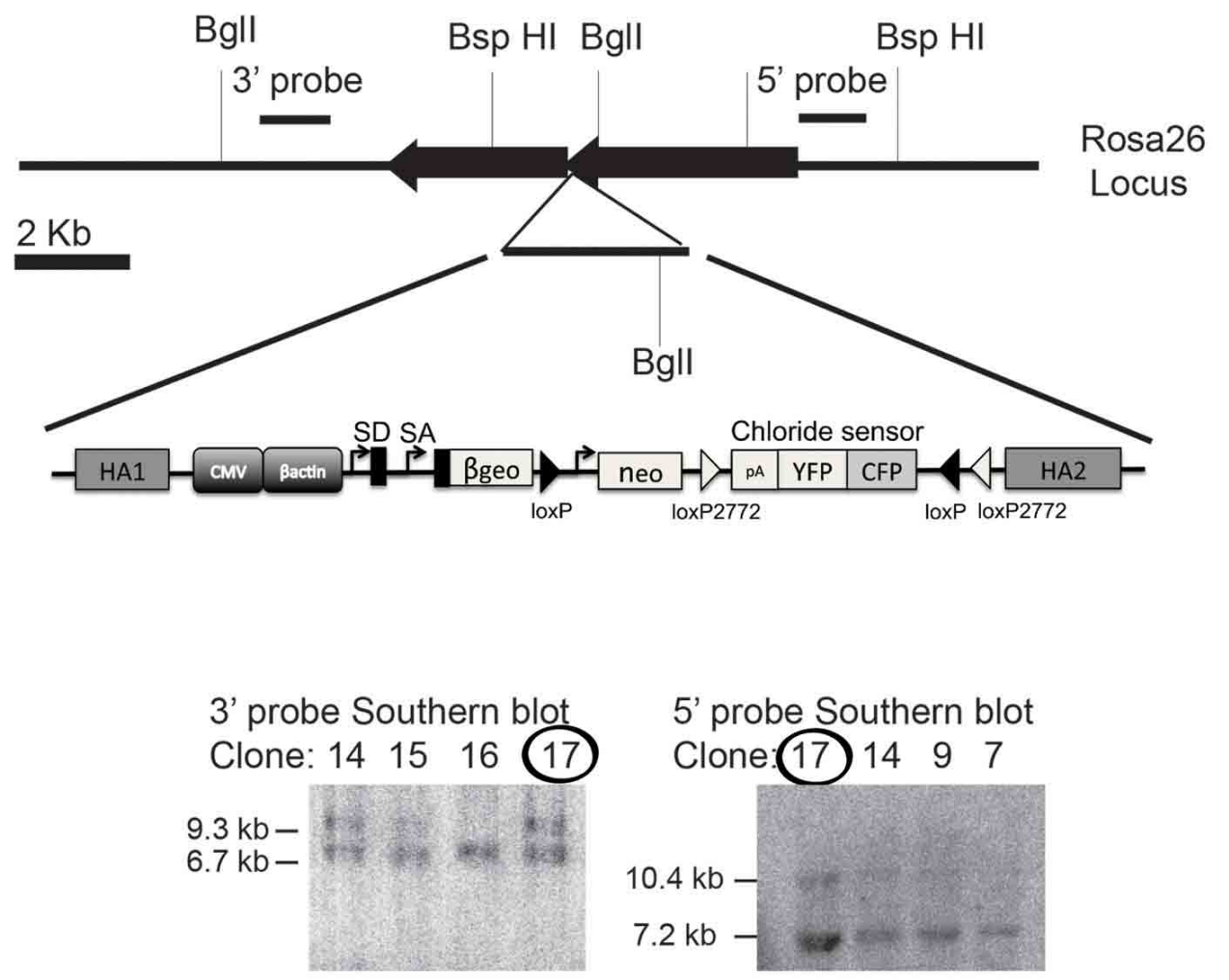

B

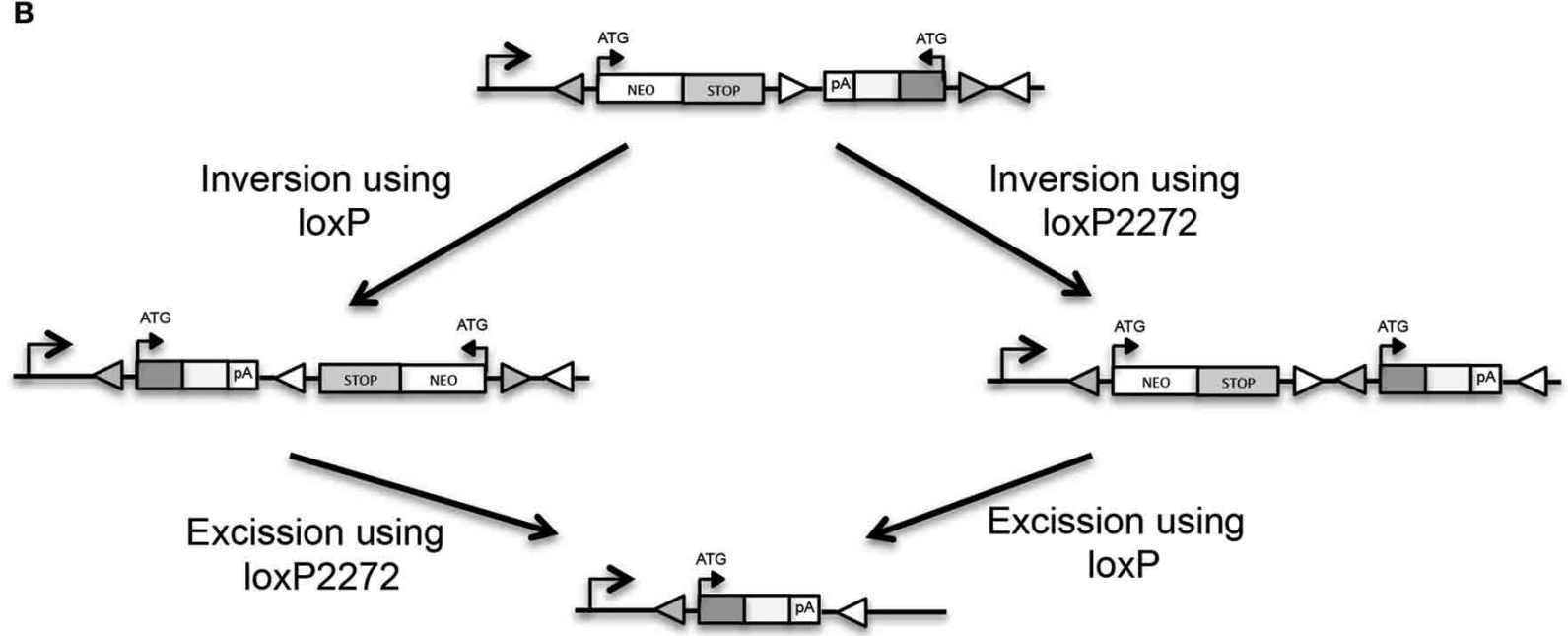

FIGURE 3 | Generation of Cl-Sensor transgenic mouse. (A) The Cl-Sensor cassettes were assembled and inserted into the Xbal site of the ROSA26 targeting vector. Southern blot was used to confirm proper homologous recombination on ES cell selected clones. Clone number 17 was selected for blastocyst injection. (B) Schematic representation of the Rosa26 locus after targeted introduction of the neomycin-Cl-Sensor cassette. The $\mathrm{Cl}$-Sensor cassette, including an SV40 polyadenylation site, is inserted in an antisense orientation. Two alternative recombination intermediates are generated by Cre-mediated inversion at the wild-type loxP sites (filled triangles), and mutant loxP2272 sites (open triangles). where $R_{C l}$ is the fluorescence ratio for $\mathrm{Cl}\left(\mathrm{F}_{440} / \mathrm{F}_{480}\right), K_{d}$ is the dissociation constant for $\mathrm{Cl}$ binding, $\mathrm{A} 1$ and $\mathrm{A} 2$ are the minimum and maximum asymptotic values of $R_{C l}$, respectively, and $p$ is the power value.
By rearranging this formula we obtained the equation for $[\mathrm{Cl}]_{\mathrm{i}}$ :

$$
[C l]_{i}=K_{d} \cdot\left(\frac{A 1-A 2}{R_{C l}-A 2}-1\right)^{\frac{1}{p}}
$$



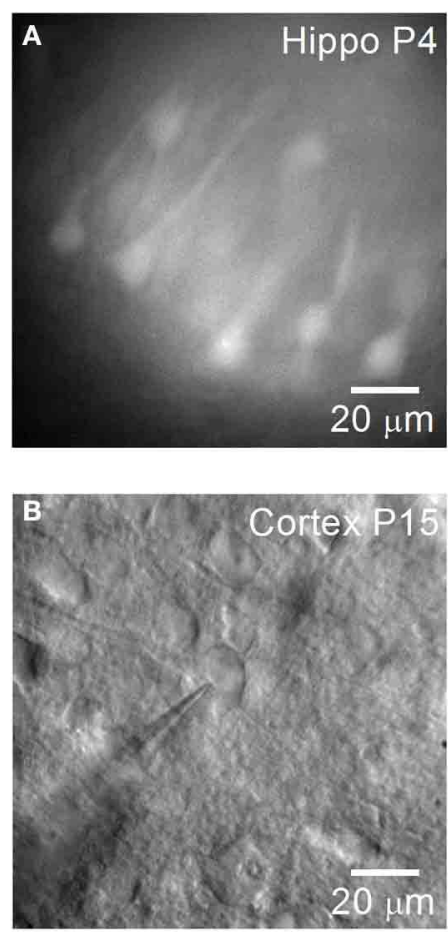

Cortex P15

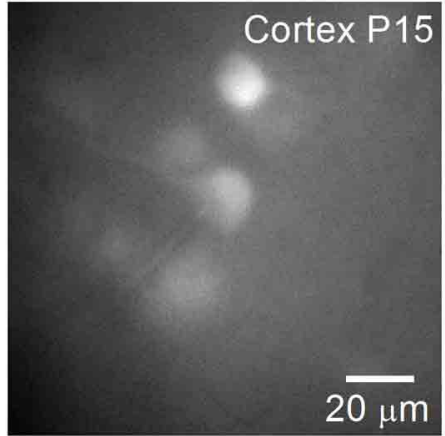

FIGURE 4 | Calibration of Cl-Sensor in brain slices of Thy1 mice. (A) Image of cells expressing $\mathrm{Cl}$-Sensor in a hippocampal slice from P4 aged Thy $1:: \mathrm{Cl}-$ Sensor mouse, excitation $480 \mathrm{~nm}$. (B) Micrographs of cells expressing $\mathrm{Cl}-$ Sensor in cortical slice from Thy 1 mouse at age P15; top, light illumination; Note the shadow of the recording pipette; bottom, excitation $480 \mathrm{~nm}$. (C) Relative changes in $R_{C l}\left(F_{440} / F_{480}\right)$ from simultaneous whole-cell recordings with different concentration of $\mathrm{Cl}$ in the recording pipette: $4 \mathrm{mM}$ (black trace), $60 \mathrm{mM}$ (b/ue trace), and $135 \mathrm{mM}$ (red
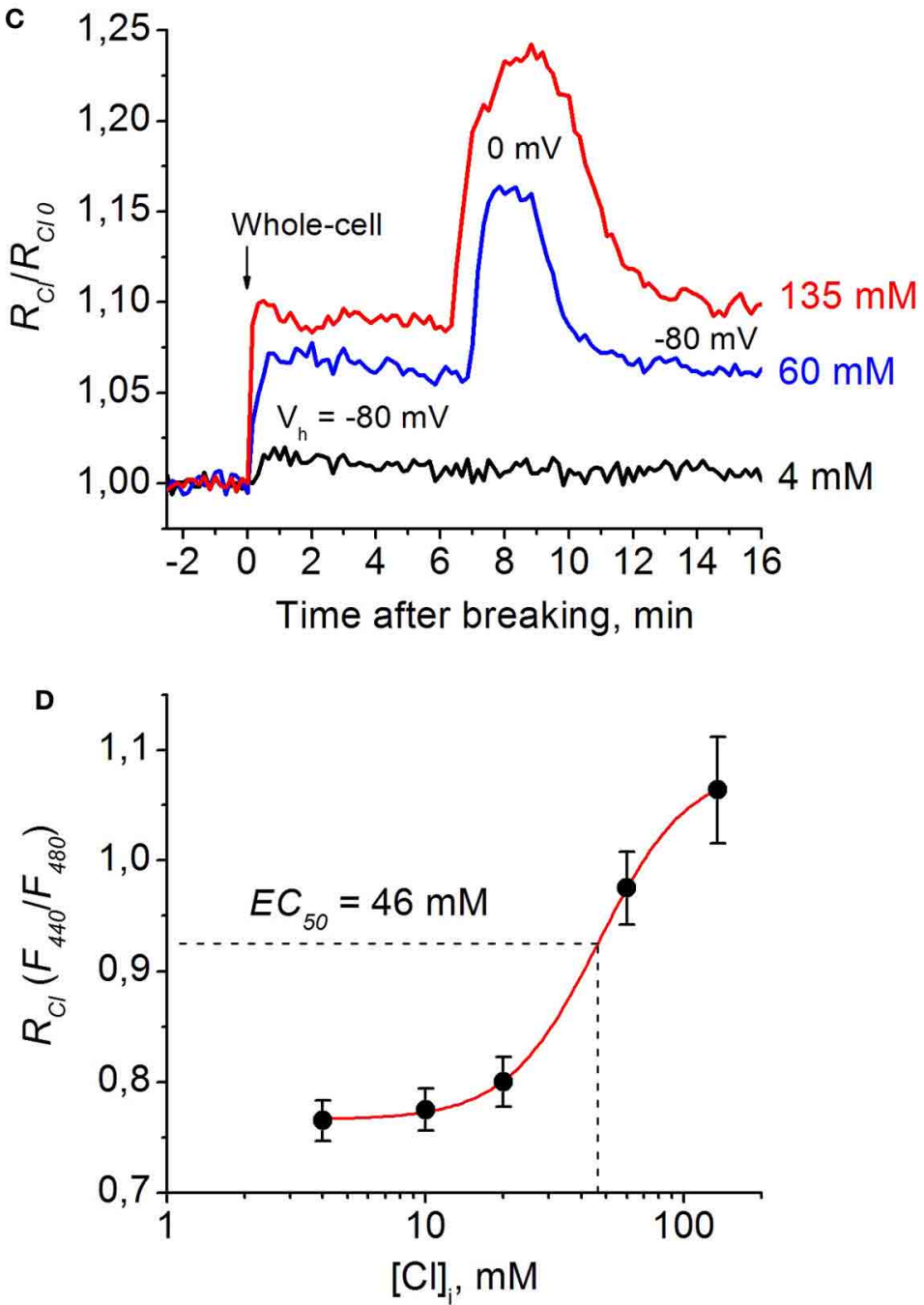

For Thy1::Cl-Sensor the values of constants obtained from fitting the curve were the following: $K_{d}=46.4 \mathrm{mM}, A 1=0.76, A 2=$ 1.08 and $p=2.48$ (Figure 4D).

Using this approach we determined that within a physiological range of $\mathrm{Cl}$ concentrations $(0-135 \mathrm{mM})$ the mean apparent $E C_{50}$ (concentration of $\mathrm{Cl}$ producing a $50 \%$ change in the fluorescence ratio, $E C_{50}$ ) of Thyl::Cl-Sensor was $46.4 \pm$ $2.2 \mathrm{mM}$ (Figure 4D, Table 1). While the sensitivity of $\mathrm{Cl}-$ Sensor to $\mathrm{Cl}$ in Thy1::Cl-Sensor mice was similar to that reported previously (Markova et al., 2008; Waseem et al., 2010), the dynamic range of $R_{C l}$ changes was about 2-3 fold smaller than those obtained in $\mathrm{CHO}$ cells and cultured trace). $R_{C / 0}$ corresponds to $[\mathrm{Cl}]_{i}$ in cell attached mode. Time $=0$ corresponds to the moment of membrane rupture into whole-cell mode. Note the further increase in $R_{C l}$ at depolarization from -80 to $0 \mathrm{mV}$ in the cells recorded with $60 \mathrm{mM}$ (blue trace) and $135 \mathrm{mM}$ (red trace) $\mathrm{Cl}$ in the pipette. (D) Calibration curve for $\mathrm{Cl}$-Sensor expressed in neurons of brain slices from Thy1 mice obtained by recording at five different $\mathrm{Cl}$ concentrations: $4,10,20,60$, and $135 \mathrm{mM}$. $E C_{50}=46.4 \pm 2.2 \mathrm{mM}$ (mean \pm S.E.M.). Data from 5 to 7 cells for each $\mathrm{Cl}$ concentration are presented. 
glycine receptor (Markova et al., 2008), application of positive potentials to neurons induced elevation of $[\mathrm{Cl}]_{\mathrm{i}}$. Thus, as illustrated in Figure 5B, changes in membrane potential from -80 to $+30 \mathrm{mV}$ using pipettes containing $135 \mathrm{mM} \mathrm{Cl}$ induced remarkable and reversible $[\mathrm{Cl}]_{\mathrm{i}}$ increase. This indicates that depolarization changes the $\mathrm{Cl}$ equilibrium and is able to do so even in cells containing very high $\mathrm{Cl}$ concentration.

It had been well documented that 4-aminopyridine (4-AP), a blocker of $\mathrm{K}^{+}$channels, induces epileptoform activity associated with ictal discharges resulting from synchronous GABA-mediated depolarizing potentials. This is accompanied by transient increases of extracellular $\mathrm{K}^{+}$(Avoli et al., 1996; Barbarosie

Table 1 | Table summarizing the $E C_{50}$ and Hill coefficient calculated on different tissue or cell culture isolated from the mouse lines described in the manuscript.

\begin{tabular}{llrl}
\hline & Mouse line & $\boldsymbol{E C}_{\mathbf{5 0}}$ (mM) & $\begin{array}{l}\text { Hill coef- } \\
\text { ficient }\end{array}$ \\
\hline Brain slice & Thy1::Cl-Sensor & $46.4 \pm 2.2$ & 2.48 \\
DRG culture & Avil-Cre::Cl-Sensor & $54.46 \pm 6.3$ & 3.12 \\
Macrophages culture & LysM-Cre::Cl-Sensor & $60.79 \pm 3.96$ & 4.46
\end{tabular}

et al., 2002) and elevation of intracellular Cl (Dzhala and Staley, 2003; Khalilov et al., 2003; Glykys et al., 2009). To visualize kinetics and amplitude of $\mathrm{Cl}$ changes in this epileptogenic model, we monitored changes of $[\mathrm{Cl}]_{\mathrm{i}}$ in neocortical slices from mice expressing $\mathrm{Cl}$-Sensor during epileptoform activity induced by 4 -AP.

Figure 5C shows a recording from two neurons. One was patch-clamped with a pipette containing $135 \mathrm{mM} \mathrm{Cl}$ while the other was left intact. Application of $100 \mu \mathrm{M} 4$-AP caused a robust and reversible elevation of $\mathrm{Cl}$ in recorded neurons. Its amplitude was even higher than those induced by membrane depolarization to $+30 \mathrm{mV}$ (Figure 5C, red trace). Importantly, the time course and amplitude of $[\mathrm{Cl}]_{\mathrm{i}}$ transients were similar in both neurons.

These initial observations indicate that transgenic mice expressing Cl-Sensor from the Thyl promoter represent a good tool for monitoring of $[\mathrm{Cl}]_{\mathrm{i}}$ transients in different experimental models.

\section{CHLORIDE MEASUREMENTS ON DISSOCIATED DRG NEURONS FROM Avil-Cre::CI-SENSOR MICE}

Using the inducible Rosa26 mouse line, we investigated the expression and function of Cl-Sensor in two separate cell types; peripheral sensory neurons, and cells of the myeloid lineage. To investigate the expression and function of Cl-Sensor in
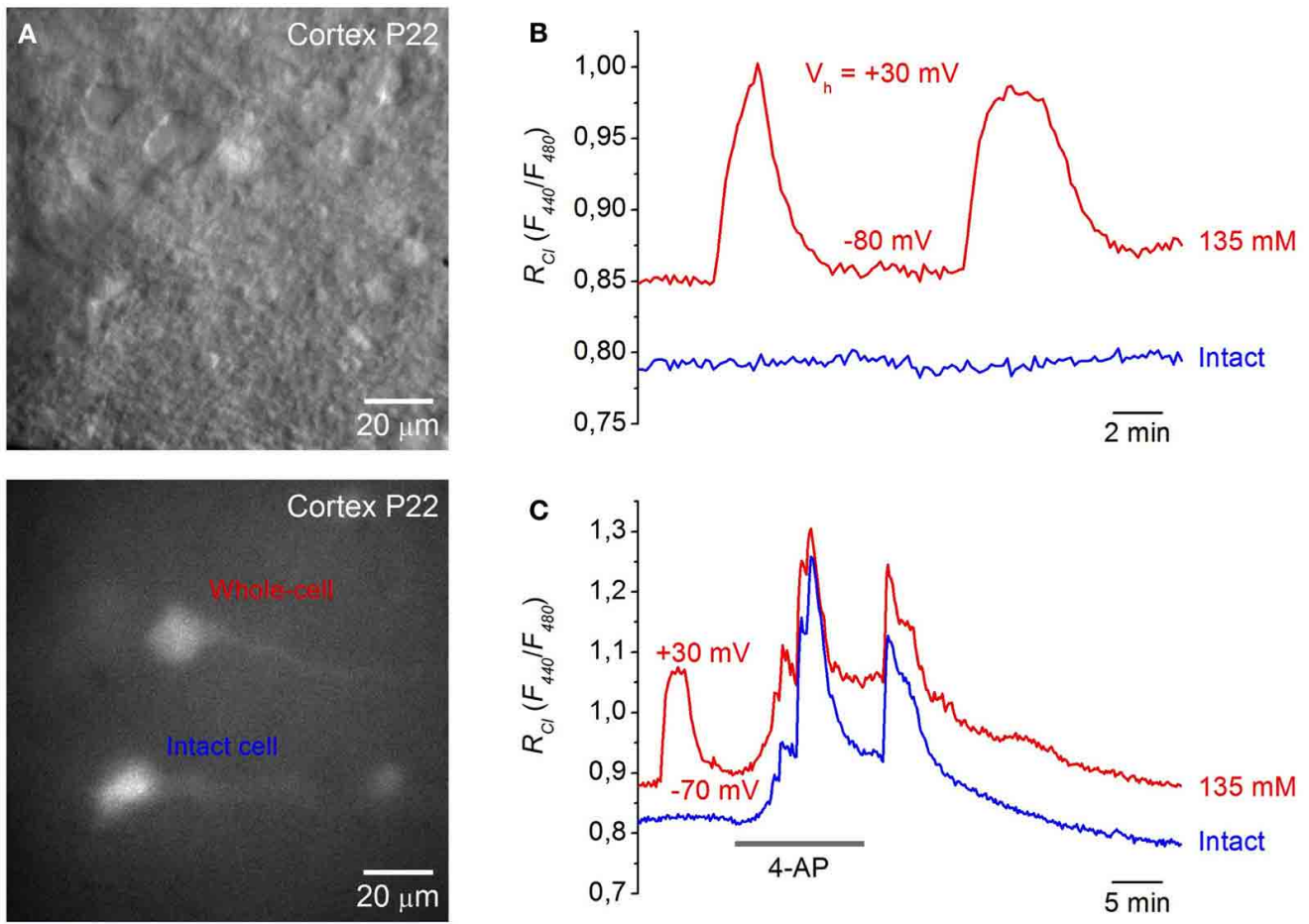

FIGURE 5 | Monitoring [Cl] in neurons from cortical brain slices. (A) Images of cells in a cortical slice from a P22 mouse expressing $\mathrm{Cl}$-Sensor in visible light (top) and excitation $480 \mathrm{~nm}$ (bottom). (B) Example of changes in $R_{C l}\left(F_{440} / F_{480}\right)$ after membrane depolarization from a holding potential of -80 to $+30 \mathrm{mV}$ in the neuron from a cortical slice (P15) recorded with pipette solution containing $135 \mathrm{mM} \mathrm{Cl}$ (red trace-whole-cell, blue trace-intact cell). Note that depolarization of the cell recorded with high $\mathrm{Cl}$ caused an additional increase in the $R_{C l}$. (C) Monitoring of epileptic-like seizures in neurons of brain slice from cortex (P22). Traces of $R_{C l}$ changes from two neurons are illustrated upon application of $100 \mu \mathrm{M}$ 4-AP. The neuron corresponding to the red trace was patched with a pipette containing $135 \mathrm{mM} \mathrm{Cl}$, while the blue trace corresponds to the record from intact neurons. Note that 4-AP application caused a stronger increase in $R_{C l}$ than depolarization from -70 to $+30 \mathrm{mV}$. 
sensory neurons, Cl-Sensor transgenic mice were crossed with an Advillin-Cre driver line, which specifically targets sensory neurons in dorsal root ganglia and trigeminal ganglia (Zurborg et al., 2011). DRG cultures were prepared from adult Avil-Cre::ClSensor mice and used for calibration of the $\mathrm{Cl}$-Sensor probe (Figure 6).

In order to increase the permeability of the cell membrane to $\mathrm{Cl}$ ions for calibration experiments, the natural triterpenoid saponin, $\beta$-escin was applied to cells. This compound has been shown to be effective for in situ calibration of $\mathrm{Cl}$ Sensor and to give more reliable results than other methods (Waseem et al., 2010). After treatment with $\beta$-escin $(40 \mu \mathrm{M})$, cells were placed in isosmotic extracellular solutions containing different concentrations of $\mathrm{Cl}$. Extracellular solutions were prepared by substituting equimolar concentrations of K-gluconate with $\mathrm{KCl}$. A Cl-free solution containing $164.8 \mathrm{~K}$-gluconate was used to determine the minimum excitation ratio of $\mathrm{Cl}$ Sensor and a solution containing $164.8 \mathrm{KCl}$ gave the maximum excitation ratio.

Ratiometric measurements of emission fluorescence at 440 and $514 \mathrm{~nm}$ excitation wavelengths (440/514) were used to calibrate the probe (Figure 6A). The estimated intracellular $\mathrm{Cl}$ concentration was plotted against the $440 / 514$ ratios and the data was fitted with a Hill equation (Figure 6B). The calculated $E C_{50}$ was $54.46 \pm 6.3 \mathrm{mM}$ (Table 1). This value resembles results described by Waseem et al., where the $E C_{50}$ was $48.9 \pm 6.3 \mathrm{mM}$, calculated on cultured spinal neurons transfected with the Cl-Sensor probe (Waseem et al., 2010).

We next examined basal intracellular $\mathrm{Cl}$ levels in DRG neurons. As illustrated in Figure 6C, calculation of the 440/514 ratio indicates that there is a broad range of estimated $[\mathrm{Cl}]_{\mathrm{i}}$ amongst DRG neurons; mean $[\mathrm{Cl}]_{\mathrm{i}}$ in DRG neurons is $58.16 \pm 1.5 \mathrm{mM}$ with a $95 \%$ of confidence interval from 55.20 to $61.11 \mathrm{mM}, n=260$. DRG neurons can be broadly classified on the basis of their size into three functionally distinct populations of "small," "medium," and "large" neurons, which approximately correspond to C, A $\delta$ and $A \alpha-A \beta$ fibers (Study and Kral, 1996). As shown in Figure 6D, fluorescence ratio was not correlated to cell size suggesting that differences in $[\mathrm{Cl}]_{\mathrm{i}}$ are not significantly different between these populations (Pearson $R=-0.076, p=0.22, n=260$ ).

\section{CHLORIDE MEASUREMENTS ON ex vivo WHOLE DRG PREPARATIONS FROM Avil-Cre::CI-SENSOR}

The analysis of Cl-Sensor in sensory neurons was extended by utilizing an ex vivo whole mount preparation of DRG (Figure 7). We reasoned that this preparation may give a more accurate representation of physiological $\mathrm{Cl}$ levels in sensory neurons than dissociated culture. For example, three dimensional architecture, cellular connectivity and density of the ganglion would be expected to be preserved in a whole mount preparation. Furthermore, tissue is

\section{A Dissociated DRG}
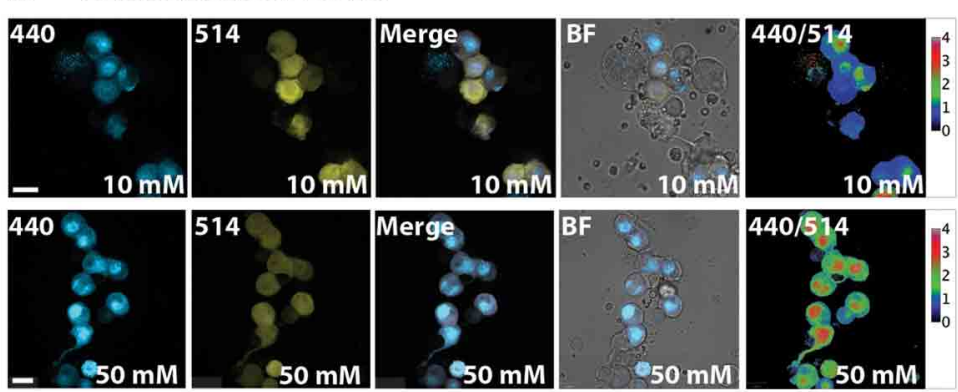

\section{B}

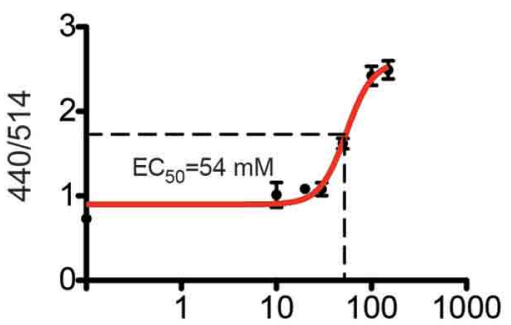

$[\mathrm{Cl}] \mathrm{i} \mathrm{mM}$

D

c Dissociated DRG
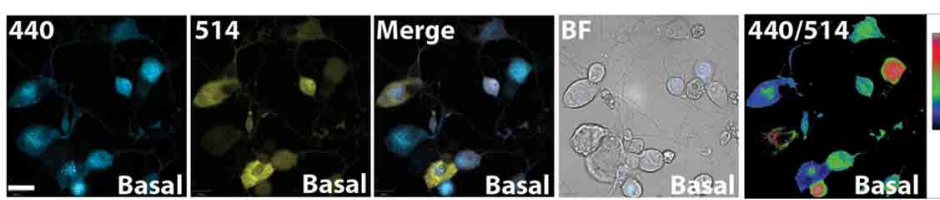

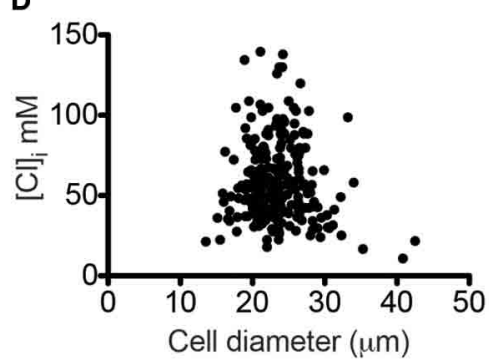

$440 / 514$ values were calculated at $0,10,20,30,50,100$, and $150 \mathrm{mM}[\mathrm{Cl}]$ $(n=55)$. (C) Examples of $[\mathrm{Cl}]_{i}$ measurement in DRG culture under basal conditions. From left to right: image captured with the $440 \mathrm{~nm}$ laser (blue), $514 \mathrm{~nm}$ laser (yellow), merged, bright field images and 440/514 images. Scale bar corresponds to $20 \mu \mathrm{m}$ (D) The relationship between cell size and [Cl] in DRG neurons $n=260$. 


\section{A} Whole mount DRG

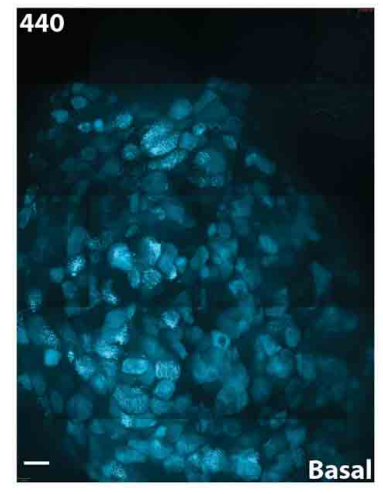

\section{B}

\section{Whole mount DRG}
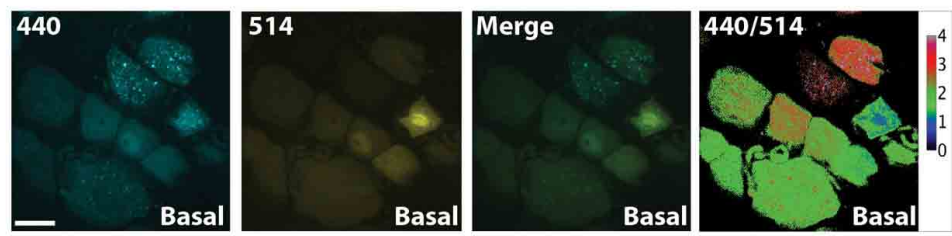

C

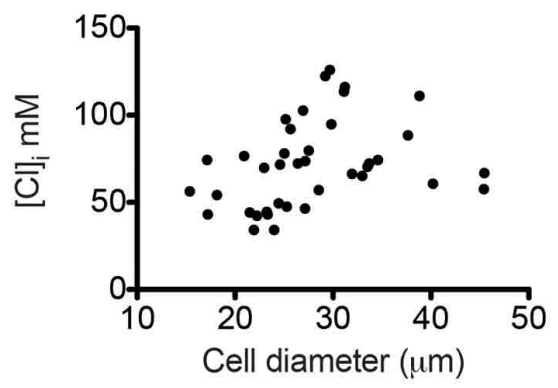

FIGURE $7 \mid[\mathrm{Cl}]_{\mathrm{i}}$ measurement on whole-mount DRG from Avil-Cre::Cl-Sensor mice. (A) An xy-plane projection of a deconvolved $75 \mu \mathrm{m}$ stack of an isolated whole-mount DRG. Tissue was excited with a $440 \mathrm{~nm}$ laser and CFP (blue) was detected. Scale bar corresponds to $200 \mu \mathrm{m}$. (B) Example of a DRG image under basal conditions used for $[\mathrm{Cl}]_{i}$ measurement. From left to right: image captured with the $440 \mathrm{~nm}$ laser (blue), $514 \mathrm{~nm}$ laser (yellow), and $440 / 514$ images. Scale bars correspond to $20 \mu \mathrm{m}$. (C) The relationship between cell size and $[\mathrm{Cl}]_{i}$ in DRG neurons from a whole mount preparation $n=39$. not subjected to a lengthy dissociation protocol which may modify ion homeostasis. Using this preparation, tissue was viable in oxygenated ACSF for at least $5 \mathrm{~h}$.

Figure 7A shows a stitched image of a whole-mount DRG and illustrates that $\mathrm{Cl}$-Sensor is robustly expressed in the majority of the DRG neurons. Analysis of $[\mathrm{Cl}]_{\mathrm{i}}$ in these neurons again demonstrated a heterogeneous distribution of $440 / 514$ ratios with a mean $[\mathrm{Cl}]_{\mathrm{i}}$ of $71.58 \mathrm{mM}$ and a $95 \%$ confidence interval from 63.21 to $78.24 \mathrm{mM}, n=39$ (Figures $7 \mathbf{B}, \mathbf{C}$ ). Of note these values were significantly higher than those observed in cultured DRG neurons $(p<0.001)$ and may reflect the increased physiological relevance of this preparation compared to dissociated neurons.

\section{CHLORIDE MEASUREMENTS ON MACROPHAGES FROM LysM-Cre::CI-SENSOR MICE}

Myeloid lineage-specific expression of Cl-Sensor was obtained by crossing Cl-Sensor transgenic mice with LysM-cre, a Credriver line targeting cells of the myeloid lineage (Clausen et al., 1999). We firstly assessed the expression and function of the transgene in peritoneal macrophages isolated from adult LysMCre::Cl-Sensor mice. Robust expression of the probe was observed in macrophages (Figure 8) that was evident in the majority of cells examined. Calibration of the probe was performed in the same way as in DRG neurons by treating cells with $\beta$-escin $(80 \mu \mathrm{M})$ and monitoring fluorescence at different $\mathrm{Cl}$ concentrations (Figure 8A). In agreement with results in DRG neurons, data was fit with a Hill equation to give an $E C_{50}$ of $60.79 \pm$ $3.96 \mathrm{mM}$ (Figure 8B and Table 1). While being slightly higher (but not significantly: $95 \%$ confidence of interval in DRG is 41.09-67.83, in macrophages is 53.0-68.5) than in previous calibrations this mean $E C_{50}$ value suggests that although a different Cre driver line was used, the ratiometric measurement can be applied with a similar output to both models. Finally, Cl-Sensor was utilized to measure basal $[\mathrm{Cl}]_{\mathrm{i}}$ in isolated macrophages. The mean concentration calculated from 181 macrophages was 65.48 with a $95 \%$ of confidence interval from 63.21 to $67.60 \mathrm{mM}$ (Figures 8C,D).

\section{DISCUSSION}

To obtain new tools for non-invasive monitoring of intracellular $\mathrm{Cl}$ concentration under normal and pathological conditions, two transgenic mouse lines were generated expressing $\mathrm{Cl}$-sensitive probes either in neurons, or targeted to the Rosa26 locus for inducible expression.

\section{Thy1::CI-SENSOR TRANSGENIC MICE}

In the first approach, Cl-Sensor (Markova et al., 2008) was expressed under the control of the neuron-specific Thyl promoter (Caroni, 1997; Feng et al., 2000; Berglund et al., 2008). Because of a triple mutation in YFP, this sensor displayed an enhanced sensitivity to $\mathrm{Cl}$ that was within the physiological range of intracellular $\mathrm{Cl}$ concentrations encountered in different cell types (Markova et al., 2008; Waseem et al., 2010). By simultaneously monitoring fluorescence and ionic currents in whole-cell patch clamp recordings with different concentrations of $\mathrm{Cl}$ in the recording pipette, we calibrated the sensor and estimated the apparent $E C_{50}$ for $\mathrm{Cl}$ to be $46 \mathrm{mM}$ (at $\mathrm{pH} 7.4$ ). This value is close to previously reported calibration data for Cl-Sensor in cell lines and neurons (Markova et al., 2008; Waseem et al., 2010). 


\section{A Macrophage cultures}
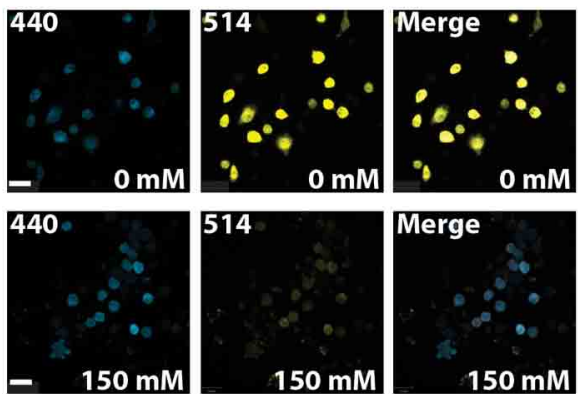

$150 \mathrm{mM}$

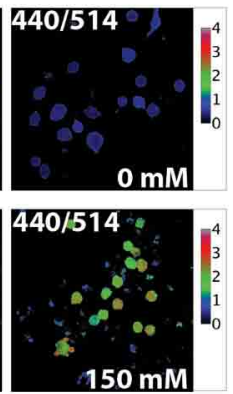

C

\section{Macrophage cultures}
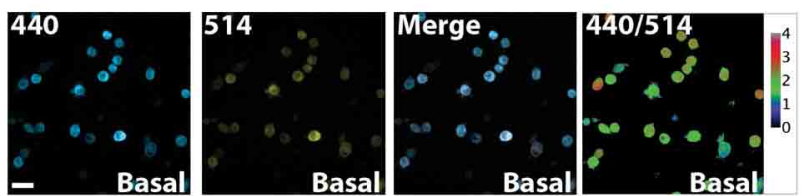

B

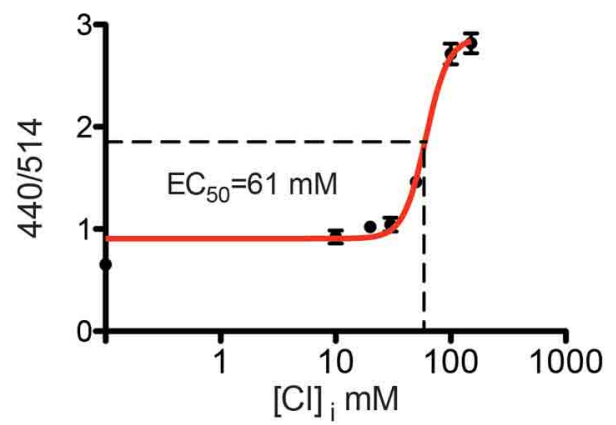

D

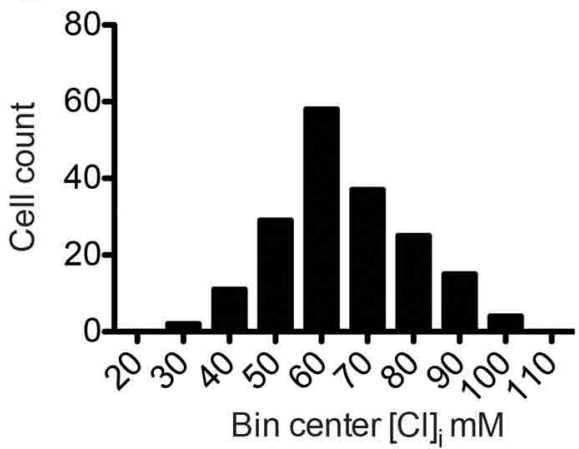

FIGURE $8 \mid[C]_{i}$ calibration and measurement in peritoneal macrophages from LysM-Cre::Cl-Sensor mice. (A) Representative images of

permeabilized peritoneal macrophages cultures which were subjected to $\beta$-escin treatment followed by the addition of $0 \mathrm{mM}$ (top) or $150 \mathrm{mM}$ (bottom) extracellular $\mathrm{Cl}^{-}$solutions. From left to right: image captured with the $440 \mathrm{~nm}$ laser (blue), $514 \mathrm{~nm}$ laser (yellow), merged and 440/514 images. Scale bars correspond to $20 \mu \mathrm{m}$. (B) [Cl] $]_{i}$ calibration curve on peritoneal macrophages cultures. 440/514 values were calculated at 0,10,20,30,50, 100, and $150 \mathrm{mM}[\mathrm{Cl}]_{\mathrm{i}}(n=225)$. (C) Images of basal $[\mathrm{Cl}]_{\mathrm{i}}$ in macrophages. (D) Histogram of $[\mathrm{Cl}]_{i}$ distribution in macrophages $(n=181)$. The distribution of $[\mathrm{Cl}]_{\mathrm{i}}$ was fit with a Gaussian curve to give a mean of $65.48 \pm 1.07 \mathrm{mM}$. Scale bars correspond to $20 \mu \mathrm{m}$.
An early study describing the Thyl cassette in transgenic mice reported that this promoter induces expression in neurons from around P6-P10 (Caroni, 1997). We observed fluorescence in hippocampal and neocortical neurons from P2 and its level increased substantially with development. $\mathrm{Cl}$ transients were observed in hippocampus (particularly in CA1 and CA3) and neocortex. Similar to previous observations (Metzger et al., 2002; Markova et al., 2008; Mukhtarov et al., 2008), depolarization induced by bath application of $\mathrm{KCl}$ or via the recording pipette brought about a strong elevation in intracellular $\mathrm{Cl}$ in neurons or brain slices.

To explore this further, the $\mathrm{K}^{+}$channel blocker, 4-AP, was applied to slices. This compound is widely used as a tool for increasing neuronal network excitatory activity, and has been shown to generate interictal-like events in human neocortical tissue via depolarization and an excitatory action at GABA receptors (Avoli et al., 1994). We used this blocker for inducing seizure-like activity and monitored $\mathrm{Cl}$ transients under these conditions. 4-AP caused a robust elevation in $[\mathrm{Cl}]_{\mathrm{i}}$, indicating that depolarization induces an increase in $\mathrm{Cl}$ driving force that promotes $\mathrm{Cl}$ influx, presumably through $\mathrm{Cl}$-selective channels or via changes in the activity of $\mathrm{Cl}$ transporters.

Two interesting features concerning $\mathrm{Cl}$ transients were observed when monitoring neurons in brain slices from Thy1::Cl-Sensor mice. Firstly, depolarization was able to induce elevation of $[\mathrm{Cl}]_{\mathrm{i}}$ : changing the $\mathrm{V}_{\mathrm{h}}$ to $0 \mathrm{mV}$ and more positive potentials caused a strong increase in $[\mathrm{Cl}]_{\mathrm{i}}$. This effect was not observed when performing similar experiments in $\mathrm{HEK}$ or $\mathrm{CHO}$ cells expressing Cl-Sensor (Markova et al., 2008), Biosensor GlyR (Mukhtarov et al., 2008) or ClopHensor (Mukhtarov et al., 2013). Secondly, in cells recorded with $135 \mathrm{mM} \mathrm{Cl}$ at a holding potential of $+30 \mathrm{mV}$, the $R_{C l}$ value was lower than that following 4-AP application (Figures 5B,C). These observation suggests that in brain slices $[\mathrm{Cl}]_{\mathrm{i}}$ does not reach $[\mathrm{Cl}]_{\mathrm{p}}$ values even at $\mathrm{V}_{h} \geq E_{C l}$. The activity of neuronal $\mathrm{Cl}$ transporters (Pellegrino et al., 2011; Friedel et al., 2013) or some other reasons may be responsible for these effects. More detailed calibration analysis of Thy1::ClSensor function in neurons in brain slices may eventually clarify these phenomena.

\section{Rosa26::CI-SENSOR TRANSGENIC MICE}

In a second approach, transgenic mice with Cl-Sensor knocked into the Rosa26 locus were generated. We used an inducible strategy where the Cl-Sensor transgene was integrated into the Rosa26 locus in a reverse orientation. Due to the arrangement of loxP and mutant loxP2272 sites, Cre-mediated recombination induces an inversion of the sensor that can be exploited for tissue specific expression (Luche et al., 2007). To validate this strategy we crossed mice with a sensory neuron specific Cre-driver line, 
Advillin-Cre (Zurborg et al., 2011), and a myeloid lineage driver LysM-Cre (Clausen et al., 1999). In both approaches, robust expression of Cl-Sensor in DRG neurons and macrophages was observed. Mice were analyzed further to determine basal $[\mathrm{Cl}]_{\mathrm{i}}$ in these different cell types.

Early reports on intracellular $\mathrm{Cl}$ concentration in peripheral neurons were based mainly on measurements of the reversal potential of $\mathrm{GABA}_{\mathrm{A}}$ receptor mediated $\mathrm{Cl}$ currents. These studies demonstrated that in primary afferent neurons, $\mathrm{GABA}_{\mathrm{A}}$ receptor activation is associated with membrane depolarization, indicating that intracellular $\mathrm{Cl}$ concentration is relatively high. (Deschenes et al., 1976; Alvarez-Leefmans et al., 1988). Indeed, $[\mathrm{Cl}]_{\mathrm{i}}$ in neurons of mammalian DRG has been estimated to be in the range 30-50 mM using both electrophysiological (Alvarez-Leefmans et al., 1988; Kenyon, 2000; Kaneko et al., 2004) and fluorescent imaging methodologies (Rocha-Gonzalez et al., 2008). These values are close to those to obtain in our experiments on dissociated DRG neurons (approximately $58 \mathrm{mM}$ ).

The elevated $[\mathrm{Cl}]_{\mathrm{i}}$ in peripheral sensory neurons appears to be due to the high expression of the $\mathrm{Na}^{+}-\mathrm{K}^{+}-\mathrm{Cl}^{-}$co-transporter (NKCC1) in these cells. In NKCC1 knockout mice, absence of the co-transporter reverses GABA-mediated currents such that strong depolarizing responses elicited by GABA in control mice become hyperpolarizing in NKCC1 null mutants (Sung et al., 2000). Using gramicidin-perforated patch-clamp recording, it has been shown that DRG neurons from wild-type animals have a $[\mathrm{Cl}]_{\mathrm{i}}$ of approximately $47 \mathrm{mM}$, while in neurons from NKCC1 knock-out mice this value is much lower at around $25 \mathrm{mM}$ (Sung et al., 2000).

A "whole mount" DRG preparation was used to determine whether $[\mathrm{Cl}]_{\mathrm{i}}$ is modified by dissociation of cells during preparation of cultures. Importantly, in whole DRG we observed higher intracellular $\mathrm{Cl}$ concentrations with a mean value of $71.58 \mathrm{mM}$. This suggests that in this intact preparation with preserved cellular connectivity and architecture, neurons are maintained in a better condition and NKCC1 is able to operate more effectively at supplying neurons with $\mathrm{Cl}$. Similarly, in a study utilizing twophoton fluorescence-lifetime imaging microscopy of the synthetic $\mathrm{Cl}$ indicator MQAE in intact DRG, mean $[\mathrm{Cl}]_{\mathrm{i}}$ was reported to be 77.2 mM (Gilbert et al., 2007).

To confirm that Rosa26::Cl-Sensor mice can also be used to examine $[\mathrm{Cl}]_{\mathrm{i}}$ in other non-neuronal cell types, mice were crossed with a LysM-Cre driver line to induce expression in cells of the myeloid lineage. We observed robust expression of Cl-Sensor in macrophages that allowed for calibration of the probe and measurement of basal $\mathrm{Cl}$ levels. Interestingly, $\mathrm{Cl}$ is considered an important anion for the function of macrophages under normal

\section{REFERENCES}

Aigner, L., Arber, S., Kapfhammer, J. P., Laux, T., Schneider, C., Botteri, F., et al. (1995). Overexpression of the neural growth-associated protein GAP-43 induces nerve sprouting in the adult nervous system of transgenic mice. Cell 83, 269-278.

Alvarez-Leefmans, F. J., Gamino, S. M., Giraldez, F., and Nogueron,
I. (1988). Intracellular chloride regulation in amphibian dorsal root ganglion neurones studied with ion-selective microelectrodes. J. Physiol. 406, 225-246.

Arenkiel, B. R., Peca, J., Davison, I. G., Feliciano, C., Deisseroth, K., Augustine, G. J., et al. (2007). In vivo light-induced activation of

and pathological conditions, and $\mathrm{Cl}$ flux has been described in macrophages at rest (Robin et al., 1971; Castranova et al., 1979) and during phagocytosis (Ince et al., 1988). Furthermore, disrupted $\mathrm{Cl}$ efflux was demonstrated in macrophages from patients with cystic fibrosis as a result of defective $\mathrm{Cl}$ secretion (Doring and Gulbins, 2009). As yet, however, the distribution and functional regulation of $[\mathrm{Cl}]_{\mathrm{i}}$ in macrophages has not been extensively explored. In our experiments we estimated the mean concentration of $\mathrm{Cl}$ in macrophages to be $65.48 \mathrm{mM}$. This value is relatively high and may reflect enhanced activity of $\mathrm{Cl}$ co-transporters or other as yet unknown mechanisms in these cells.

The constructs described here, in line with other fluorescent proteins from the GFP family, exhibit a relatively high sensitivity to $\mathrm{pH}$ variations. Earlier we showed that for Cl-Sensor, a shift of $\mathrm{pH}$ by 0.1 units results in a change in the ratio for $\mathrm{Cl}$ estimation by at most $6 \%$ of the whole dynamic range of the probe (Markova et al., 2008). In addition YFP-based molecules are also sensitive to some organic anions (Jayaraman et al., 2000). These points should be taken into account when using these probes and transgenic animals. To circumvent these problems, a combined $\mathrm{Cl} / \mathrm{pH}$ sensor was recently described (Arosio et al., 2010) which along with its derivatives (Mukhtarov et al., 2013) allows simultaneous ratiometric measurement of these two ions. For these probes, however, transgenic models have not yet been developed.

In conclusion, we have developed transgenic mice that express $\mathrm{Cl}-$ Sensor in different cell types, including neurons. The sensitivity and the fact that the probe is genetically encoded should greatly facilitate non-invasive monitoring of $[\mathrm{Cl}]_{\mathrm{i}}$ and allow for the analysis of $\mathrm{Cl}$ transients in vivo. Transgenic mice expressing $\mathrm{Cl}$-Sensor under the control of cell-type specific promoters provide a novel tool for the functional characterization of intracellular $\mathrm{Cl}$ distribution in defined subsets of neurons in various experimental models.

\section{ACKNOWLEDGMENTS}

This study was technically supported by the EMBL Transgenic Facility and the EMBL Monterotondo Microscopy Facility. Marat Mukhtarov was supported by the European Union Seventh Framework Programme under grant agreement no. HEALTH-F22008-202088 ("Neurocypres" Project). Laura Batti was supported by Seventh Framework Programme Intra-European Fellowships (IEF).

\section{SUPPLEMENTARY MATERIAL}

The Supplementary Material for this article can be found online at: http://www.frontiersin.org/Molecular_Neuroscience/10.3389/ fnmol.2013.00011/abstract

neural circuitry in transgenic mice expressing channelrhodopsin-2. Neuron 54, 205-218.

Arosio, D., Ricci, F., Marchetti, L., Gualdani, R., Albertazzi, L., and Beltram, F. (2010). Simultaneous intracellular chloride and $\mathrm{pH}$ measurements using a GFPbased sensor. Nat. Methods 7, 516-518.
Avoli, M., Barbarosie, M., Lucke, A., Nagao, T., Lopantsev, V., and Kohling, R. (1996). Synchronous GABA-mediated potentials and epileptiform discharges in the rat limbic system in vitro. J. Neurosci. 16, 3912-3924.

Avoli, M., Mattia, D., Siniscalchi, A., Perreault, P., and Tomaiuolo, F. (1994). Pharmacology and 
electrophysiology of a synchronous GABA-mediated potential in the human neocortex. Neuroscience 62, 655-666.

Barbarosie, M., Louvel, J., D’Antuono, M., Kurcewicz, I., and Avoli, M. (2002). Masking synchronous GABA-mediated potentials controls limbic seizures. Epilepsia 43, 1469-1479.

Berglund, K., Schleich, W., Wang, H., Feng, G., Hall, W. C., Kuner, T., et al. (2008). Imaging synaptic inhibition throughout the brain via genetically targeted Clomeleon. Brain Cell Biol. $36,101-118$.

Bregestovski, P., and Arosio, D. (2012). "Green fluorescent protein-based chloride ion sensors for in vivo imaging," in Fluorescent Proteins II, Springer Ser Fluoresc, ed, G. Jung. (Berlin, Heidelberg: SpringerVerlag), 12, 99-124.

Bregestovski, P., Waseem, T., and Mukhtarov, M. (2009). Genetically encoded optical sensors for monitoring of intracellular chloride and chloride-selective channel activity. Front. Mol. Neurosci. 2:15. doi: 10.3389/neuro.02.015.2009

Caroni, P. (1997). Overexpression of growth-associated proteins in the neurons of adult transgenic mice. J. Neurosci. Methods 71, 3-9.

Caspani, O., Zurborg, S., Labuz, D., and Heppenstall, P. A. (2009). The contribution of TRPM8 and TRPA1 channels to cold allodynia and neuropathic pain. PLoS ONE 4:e7383. doi: 10.1371/journal.pone. 0007383

Castranova, V., Bowman, L., and Miles, P. R. (1979). Transmembrane potential and ionic content of rat alveolar macrophages. J. Cell Physiol. 101, 471-479.

Clausen, B. E., Burkhardt, C., Reith, W., Renkawitz, R., and Forster, I. (1999). Conditional gene targeting in macrophages and granulocytes using LysMcre mice. Transgenic Res. 8, 265-277.

Depry, C., Mehta, S., and Zhang, J. (2013). Multiplexed visualization of dynamic signaling networks using genetically encoded fluorescent protein-based biosensors. Pflugers Arch. 465, 373-381.

Deschenes, M., Feltz, P., and Lamour, Y. (1976). A model for an estimate in vivo of the ionic basis of presynaptic inhibition: an intracellular analysis of the GABA-induced depolarization in rat dorsal root ganglia. Brain Res. 118, 486-493.

Doring, G., and Gulbins, E. (2009). Cystic fibrosis and innate immunity: how chloride channel mutations provoke lung disease. Cell Microbiol. $11,208-216$.
Duebel, J., Haverkamp, S., Schleich, W., Feng, G., Augustine, G. J., Kuner, T., et al. (2006). Twophoton imaging reveals somatodendritic chloride gradient in retinal ON-type bipolar cells expressing the biosensor Clomeleon. Neuron 49, 81-94.

Dzhala, V., Valeeva, G., Glykys, J., Khazipov, R., and Staley, K. (2012). Traumatic alterations in GABA signaling disrupt hippocampal network activity in the developing brain. J. Neurosci. 32, 4017-4031.

Dzhala, V. I., and Staley, K. J. (2003). Excitatory actions of endogenously released GABA contribute to initiation of ictal epileptiform activity in the developing hippocampus. J. Neurosci. 23, 1840-1846.

Feng, G., Mellor, R. H., Bernstein, M., Keller-Peck, C., Nguyen, Q. T., Wallace, M., et al. (2000). Imaging neuronal subsets in transgenic mice expressing multiple spectral variants of GFP. Neuron 28, 41-51.

Friedel, P., Bregestovski, P., and Medina, I. (2013). Improved method for efficient imaging of intracellular $\mathrm{Cl}(-)$ with $\mathrm{Cl}$-Sensor using conventional fluorescence setup. Front. Mol. Neurosci. 6:7. doi: 10.3389/fnmol.2013.00007

Gilbert, D., Franjic-Wurtz, C., Funk, K., Gensch, T., Frings, S., and Mohrlen, F. (2007). Differential maturation of chloride homeostasis in primary afferent neurons of the somatosensory system. Int. J. Dev. Neurosci. 25, 479-489.

Glykys, J., Dzhala, V. I., Kuchibhotla, K. V., Feng, G., Kuner, T., Augustine, G., et al. (2009). Differences in cortical versus subcortical GABAergic signaling: a candidate mechanism of electroclinical uncoupling of neonatal seizures. Neuron 63, 657-672.

Heim, R. (1999). Green fluorescent protein forms for energy transfer. Methods Enzymol. 302, 408-423.

Ince, C., Coremans, J. M., Ypey, D. L., Leijh, P. C., Verveen, A. A., and van Furth, R. (1988). Phagocytosis by human macrophages is accompanied by changes in ionic channel currents. J. Cell Biol. 106, 1873-1878.

Jayaraman, S., Haggie, P., Wachter, R. M., Remington, S. J., and Verkman, A. S. (2000). Mechanism and cellular applications of a green fluorescent protein-based halide sensor. J. Biol. Chem. 275, 6047-6050.

Kaneko, H., Putzier, I., Frings, S., Kaupp, U. B., and Gensch, T.
(2004). Chloride accumulation in mammalian olfactory sensory neurons. J. Neurosci. 24 7931-7938.

Kenyon, J. L. (2000). The reversal potential of $\mathrm{Ca}(2+)$-activated $\mathrm{Cl}(-)$ currents indicates that chick sensory neurons accumulate intracellular Cl(-). Neurosci. Lett. 296, 9-12.

Khalilov, I., Holmes, G. L., and BenAri, Y. (2003). In vitro formation of a secondary epileptogenic mirror focus by interhippocampal propagation of seizures. Nat. Neurosci. 6, 1079-1085.

Kneen, M., Farinas, J., Li, Y., and Verkman, A. S. (1998). Green fluorescent protein as a noninvasive intracellular $\mathrm{pH}$ indicator. Biophys. J. 74, 1591-1599.

Kozak, M. (1987). At least six nucleotides preceding the AUG initiator codon enhance translation in mammalian cells. J. Mol. Biol. 196, 947-950.

Kuner, T., and Augustine, G. J. (2000) A genetically encoded ratiometric indicator for chloride: capturing chloride transients in cultured hippocampal neurons. Neuron 27, 447-459.

Li, Y., and Tsien, R. W. (2012). pHTomato, a red, genetically encoded indicator that enables multiplex interrogation of synaptic activity. Nat. Neurosci. 15 1047-1053.

Llopis, J., McCaffery, J. M., Miyawaki, A., Farquhar, M. G., and Tsien, R. Y. (1998). Measurement of cytosolic, mitochondrial, and Golgi $\mathrm{pH}$ in single living cells with green fluorescent proteins. Proc. Natl. Acad. Sci. U.S.A. 95, 6803-6808.

Lorenzen, I., Aberle, T., and Plieth, C. (2004). Salt stress-induced chloride flux: a study using transgenic Arabidopsis expressing a fluorescent anion probe. Plant J. 38, 539-544.

Luche, H., Weber, O., Nageswara Rao, T., Blum, C., and Fehling, H. J. (2007). Faithful activation of an extra-bright red fluorescent protein in "knock-in" Cre-reporter mice ideally suited for lineage tracing studies. Eur. J. Immunol. 37, 43-53.

Markova, O., Mukhtarov, M., Real, E., Jacob, Y., and Bregestovski, P. (2008). Genetically encoded chloride indicator with improved sensitivity. J. Neurosci. Methods 170, 67-76.

Metzger, F., Repunte-Canonigo, V., Matsushita, S., Akemann, W. Diez-Garcia, J., Ho, C. S., et al. (2002). Transgenic mice expressing a $\mathrm{pH}$ and $\mathrm{Cl}$ - sensing yellowfluorescent protein under the control of a potassium channel promoter. Eur. J. Neurosci. 15, 40-50.

Miesenbock, G., De Angelis, D. A., and Rothman, J. E. (1998). Visualizing secretion and synaptic transmission with $\mathrm{pH}$-sensitive green fluorescent proteins. Nature 394, 192-195.

Miyawaki, A., Llopis, J., Heim, R., McCaffery, J. M., Adams, J. A., Ikura, M., et al. (1997). Fluorescent indicators for $\mathrm{Ca} 2+$ based on green fluorescent proteins and calmodulin. Nature 388, 882-887.

Mukhtarov, M., Liguori, L., Waseem, Y., Rocca, F., Buldakova, S., Arosio, D., et al. (2013). Calibration and functional analysis of three genetically encoded $\mathrm{Cl}-/ \mathrm{pH}$ sensors. Front. Mol. Neurosci. 6:9. doi: 10.3389/fnmol.2013.00009

Mukhtarov, M., Markova, O., Real, E., Jacob, Y., Buldakova, S., and Bregestovski, P. (2008). Monitoring of chloride and activity of glycine receptor channels using genetically encoded fluorescent sensors. Philos. Transact. A Math. Phys. Eng. Sci. 366, 3445-3462.

Ohkura, M., Sasaki, T., Kobayashi, C., Ikegaya, Y., and Nakai, J. (2012). An improved genetically encoded red fluorescent $\mathrm{Ca} 2+$ indicator for detecting optically evoked action potentials. PLoS ONE 7:e39933. doi: 10.1371/journal.pone.0039933

Pellegrino, C., Gubkina, O., Schaefer, M., Becq, H., Ludwig, A., Mukhtarov, M., et al. (2011). Knocking down of the KCC2 in rat hippocampal neurons increases intracellular chloride concentration and compromises neuronal survival. J. Physiol. 589, 2475-2496.

Perron, A., Akemann, W., Mutoh, H., and Knopfel, T. (2012). Genetically encoded probes for optical imaging of brain electrical activity. Prog. Brain Res. 196, 63-77.

Pond, B. B., Berglund, K., Kuner, T., Feng, G., Augustine, G. J., and Schwartz-Bloom, R. D. (2006). The chloride transporter $\mathrm{Na}(+)-\mathrm{K}(+)-\mathrm{Cl}-\quad$ cotransporter isoform-1 contributes to intracellular chloride increases after in vitro ischemia. J. Neurosci. 26 1396-1406.

Robin, E. D., Smith, J. D., Tanser, A. R., Adamson, J. S., Millen, J. E., and Packer, B. (1971). Ion and macromolecular transport in the alveolar macrophage. Biochim. Biophys. Acta 241, 117-128. 
Rocha-Gonzalez, H. I., Mao, S., and Alvarez-Leefmans, F. J. (2008). $\mathrm{Na}+, \mathrm{K}+, \quad 2 \mathrm{Cl}-$ cotransport and intracellular chloride regulation in rat primary sensory neurons: thermodynamic and kinetic aspects. J. Neurophysiol. 100, 169-184.

Sauer, B. (1987). Functional expression of the cre-lox site-specific recombination system in the yeast Saccharomyces cerevisiae. Mol. Cell Biol. 7, 2087-2096.

Siegel, R. W., Jain, R., and Bradbury, A. (2001). Using an in vivo phagemid system to identify non-compatible loxP sequences. FEBS Lett. 505, 467-473.

Soriano, P. (1999). Generalized lacZ expression with the ROSA26 Cre reporter strain. Nat. Genet. 21, 70-71.
Study, R. E., and Kral, M. G. (1996). Spontaneous action potential activity in isolated dorsal root ganglion neurons from rats with a painful neuropathy. Pain 65, 235-242.

Sung, K. W., Kirby, M., McDonald, M. P., Lovinger, D. M., and Delpire, E. (2000). Abnormal GABAA receptor-mediated currents in dorsal root ganglion neurons isolated from $\mathrm{Na}-\mathrm{K}-2 \mathrm{Cl}$ cotransporter null mice. J. Neurosci. 20, 7531-7538.

Thomas, K. R., and Capecchi, M. R. (1987). Site-directed mutagenesis by gene targeting in mouse embryo-derived stem cells. Cell 51, 503-512.

Wachter, R. M., and Remington, S. J. (1999). Sensitivity of the yellow variant of green fluorescent protein to halides and nitrate. Curr. Biol. 9, R628-R629.
Waseem, T., Mukhtarov, M., Buldakova, S., Medina, I., and Bregestovski, P. (2010). Genetically encoded Cl-Sensor as a tool for monitoring of Cl-dependent processes in small neuronal compartments. J. Neurosci. Methods 193, 14-23.

Zurborg, S., Piszczek, A., Martinez, C., Hublitz, P., Al Banchaabouchi, M., Moreira, P., et al. (2011). Generation and characterization of an Advillin-Cre driver mouse line. Mol. Pain 7:66. doi: 10.1186/17448069-7-66

Conflict of Interest Statement: The authors declare that the research was conducted in the absence of any commercial or financial relationships that could be construed as a potential conflict of interest.
Received: 18 January 2013; accepted: 26 April 2013; published online: 21 May 2013.

Citation: Batti L, Mukhtarov M, Audero E, Ivanov A, Paolicelli RC, Zurborg S, Gross C, Bregestovski $P$ and Heppenstall $P A$ (2013) Transgenic mouse lines for non-invasive ratiometric monitoring of intracellular chloride. Front. Mol. Neurosci. 6:11. doi: 10.3389/fnmol. 2013.00011

Copyright (C) 2013 Batti, Mukhtarov, Audero, Ivanov, Paolicelli, Zurborg, Gross, Bregestovski and Heppenstall. This is an open-access article distributed under the terms of the Creative Commons Attribution License, which permits use, distribution and reproduction in other forums, provided the original authors and source are credited and subject to any copyright notices concerning any third-party graphics etc. 